Giovanna Ribeiro Paiva de Souza

\title{
Labor Market Conditions and Gender Inequality: Evidence from the Brazilian Trade Liberalization
}

Dissertation presented to the Programa de Pós-graduação em Economia of PUC-Rio in partial fulfillment of the requirements for the degree of Mestre em Economia.

Advisor: Prof. Gabriel Lopes de Ulyssea 


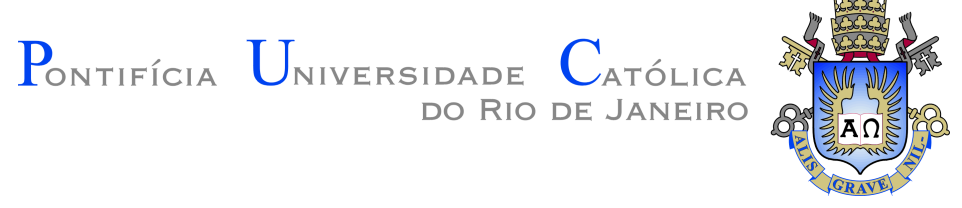

Giovanna Ribeiro Paiva de Souza

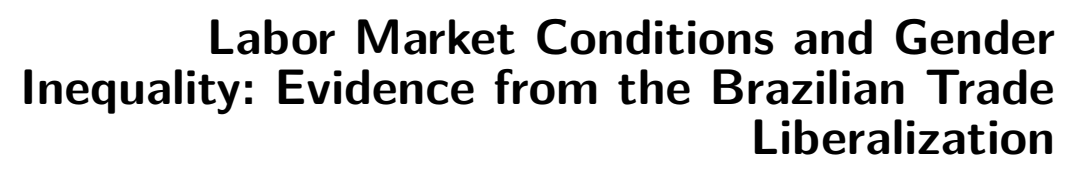

Dissertation presented to the Programa de Pós-graduação em Economia of PUC-Rio in partial fulfillment of the requirements for the degree of Mestre em Economia. Approved by the undersigned Examination Committee.

Prof. Gabriel Lopes de Ulyssea

Advisor

Departamento de Economia - PUC-Rio

Prof. Miguel Nathan Foguel

Departamento de Economia - PUC-Rio

Prof. Cecilia Machado

Escola Brasileira de Economia e Finanças - FGV/EPGE

Prof. Monica Herz

Vice Dean of Graduate Studies

Centro de Ciências Sociais - PUC-Rio

Rio de Janeiro, April 7th, 2017 
All rights reserved.

\section{Giovanna Ribeiro Paiva de Souza}

B.A., Economics, Ibmec, Rio de Janeiro, 2014.

Ficha Catalográfica

Ribeiro Paiva de Souza, Giovanna

Labor Market Conditions and Gender Inequality: Evidence from the Brazilian Trade Liberalization / Giovanna Ribeiro Paiva de Souza; orientador: Gabriel Lopes de Ulyssea. - 2017.

v., 57 f: il. color. ; $30 \mathrm{~cm}$

Dissertação (mestrado) - Pontifícia Universidade Católica do Rio de Janeiro, Departamento de Economia.

Inclui bibliografia

1. Economia - Teses. 2. Mercado de Trabalho;. 3. Desigualdade de Gênero;. 4. Liberalização Comercial;. I. Ulyssea, Gabriel Lopes de. II. Pontifícia Universidade Católica do Rio de Janeiro. Departamento de Economia. III. Título.

CDD: 330 


\section{Acknowledgments}

I would like to thank my parents, Monica and João Cesar, and my brother, Victor Hugo, for always believe, trust and support me. I would not have come this far if it had not been for you. I am thankful for all the patience and love from my boyfriend, Leonardo. I also thank my family and friends, who always cheered for me.

I really thank my advisor, Gabriel Ulyssea, for the guidance and rigor, which challenged and helped me grow professionally.

Special thanks to the department professors and my class friends, who shared their knowledge and inspired me during these years. I am also thankful for the

$\stackrel{\circ}{\widetilde{\gamma}} \quad$ help from the department staff. Financial support from CAPES is gratefully $\stackrel{0}{\mathrm{0}}$ acknowledge. 


\section{Abstract}

Ribeiro Paiva de Souza, Giovanna; Ulyssea, Gabriel Lopes de (Advisor). Labor Market Conditions and Gender Inequality: Evidence from the Brazilian Trade Liberalization. Rio de Janeiro, 2017. 57p. Dissertação de Mestrado - Departamento de Economia, Pontifícia Universidade Católica do Rio de Janeiro.

This paper studies the effect of a large and plausibly exogenous tradeinduced shock on gender inequality in the labor market. In the 1990's, Brazilian government decided to reduce import tariffs, inducing a large, once and for all trade liberalization, with heterogeneous effects across local economies. Using Brazilian Decennial Censuses, I estimate medium (19912000) and long (1991-2010) term effects of this shock to labor market outcomes separately by gender and its consequences for gender inequality. I provide a conceptual model of occupational segregation to rationalize the results. Finally, I also examine potential implications of this shock to the marriage market and individuals' human capital accumulation. Results point that, in the medium run, in harder hit regions there was an increase in the gender wage gap and women proportionally faced higher increase in nonemployment compared to men. In the long run, the losses in employment in the tradable sector remained, but in the as a whole economy they disappeared, while the gender wage gap in non-tradables decreased. Besides that, both in the medium and long run, there was an increase in human capital accumulation, at the same that the share of women that are married and have children decreased. In light of the model, these findings emphasize the importance of paying attention not only to the wage inequality, but also to the unequal distribution of genders between occupations.

\section{Keywords}

Labor Market; Gender Inequality; Trade Liberalization; 


\section{Resumo}

Ribeiro Paiva de Souza, Giovanna; Ulyssea, Gabriel Lopes de. Condições do Mercado de Trabalho e Desigualdade de Gênero: Evidência da Liberalização Comercial Brasileira. Rio de Janeiro, 2017. 57p. Dissertação de Mestrado - Departamento de Economia, Pontifícia Universidade Católica do Rio de Janeiro.

Esse artigo estuda o efeito de um choque grande e plausivelmente exógeno induzido pelo comércio sobre a desigualdade de gênero no mercado de trabalho. Nos anos 1990, o governo brasileiro decidiu reduzir as tarifas de importação, induzindo uma liberalização comercial grande e de uma vez por todas, com efeitos heterogêneos entre as economias locais. Usando Censos Decenais brasileiros, eu estimo efeitos de médio (1991-2000) e longo (1991-2010) prazos desse choque sobre os resultados do mercado de trabalho separadamente por gênero e suas consequências para a desigualdade de gênero. Eu forneço um modelo conceitual de segregação ocupacional para racionalizar os resultados. Finalmente, também examino potenciais implicações desse choque para o mercado de casamentos e a acumulação de capital humano dos indivíduos. Os resultados apontam que, no médio prazo, em regiões mais afetadas, houve um aumento no diferencial salarial por gênero e as mulheres enfrentaram proporcionalmente maior aumento no não-emprego em comparação com os homens. No longo prazo, as perdas de emprego permaneceram no setor de bens comercializáveis, mas na economia como um todo elas desapareceram, enquanto o diferencial salarial entre homens e mulheres diminuiu no setor de não comercializáveis. Além disso, tanto no médio como no longo prazo, houve um aumento na acumulação de capital humano, ao mesmo tempo em que a parcela de mulheres casadas e que têm filhos diminuiu. À luz do modelo, esses resultados enfatizam a importância de se prestar atenção não só à desigualdade salarial, mas também à distribuição desigual dos gêneros entre as ocupações.

\section{Palavras-chave}

Mercado de Trabalho; Desigualdade de Gênero; Liberalização Comercial; 


\section{Table of contents}

$\begin{array}{lll}1 & \text { Introduction } & 10\end{array}$

2 The Trade Liberalization in Brazil $\quad 15$

$\begin{array}{lll}2.1 & \text { Regional Tariff Change } & 17\end{array}$

$\begin{array}{lll}3 & \text { Data } & 19\end{array}$

$4 \quad$ Empirical Strategy $\quad 23$

4.1 First Step 24

4.2 Second Step 24

$\begin{array}{ll}4.3 \text { Conceptual Framework } & 26\end{array}$

$\begin{array}{ll}\text { 4.3.1 Comparative Static } & 29\end{array}$

5 Results $\quad 31$

5.1 Labor Market Effects $\quad 31$

5.2 Potential Consequences of Labor Market Effects 38

5.2.1 Human Capital Accumulation 39

5.2.2 Marriage Market 42

6 Conclusion $\quad 44$

A Tariff Changes and Women Employment 48

$\begin{array}{lll}\text { B Additional Statistics } & 49\end{array}$

C Additional Results $\quad 50$

C.1 Exploring Additional Heterogeneity 52

$\begin{array}{ll}\text { C.2 Looking at all workers } & 56\end{array}$ 


\section{List of figures}

2.1 Tariff Changes 1990-1995, (1) 16

2.2 Share of Women across Industries 17

3.1 Regional Tariff Changes across Brazil, $R T C_{m}$, (2) 19

A.1 Share of Women across Industries 48 


\section{List of tables}

3.1 Labor Market Summary Statistics across Micro-regions 21

3.2 Distribution of Labor Market Outcomes across Tradables and Nontradables

5.1 Conditional Wage Gap 32

5.2 Share of Tradables and Non-tradables 34

5.3 Summary of Medium-term Effects on Conditional Wage Gap 35

5.4 Share of Women in Tradables and Non-tradables 36

$\begin{array}{ll}5.5 & \text { Occupation Rate } \\ 5.6 & 37\end{array}$

5.6 Participation Rate 38

5.7 Share of Women Among Occupied 39

5.8 Summary of Medium and Long-term Effects 40

5.9 Share of Skilled Individuals 41

5.10 Years of Schooling $\quad 42$

5.11 Marriage Market 43

B.1 Labor Market Summary Statistics $\quad 49$

C.1 Share of Employees $\quad 50$

C.2 Share of Self-Employed 51

C.3 Occupation Rate: Low-Skilled 52

C.4 Occupation Rate: High-Skilled 53

C.5 Participation Rate: Low-Skilled 53

C.6 Participation Rate: High-Skilled 54

C.7 Share of Women among Occupied by Skill

C.8 Conditional Wage Gap by Skill $\quad 55$

C.9 Share of Tradables and Non-tradables 56

C.10 Share of Women in Tradables and Non-tradables 57 


\section{Introduction}

Gender inequality has been a constant theme of the political and economic debate, with discussions addressing issues like wages, social and civil rights, and the role of women in society. Despite reduction of the gap in wages over time, even developed economies still have sizeable gender wage gap ${ }^{1}$. Achieving equality is a desirable goal in itself, specially in developing economies, as women's empowerment and economic development are intimately related, with one reinforcing the other. In particular, (5) argues that "(...) improving the opportunities available to women in the labor market would provide a strong catalyst for the treatment of women to change for the better. (...)". That is because changes in the situation of women in the labor market can lead to changes in other dimensions of their lives in a self-fulfilling cycle.

An extensive literature assesses the reasons for this inequality. As reviewed in (6), there are arguments that differences exist because women and men differ in their preferences about types of work. Therefore, these differences determine the distribution of workers between occupations and, consequently, the distribution of wages. Additionally, workers of different genders may have distinct comparative advantage across occupations, what influences their allocation. Moreover, women and men may invest in human capital accumulation both prior to labor force entry and during the work years in different proportion. However, an important thing to note in relation to these reasons is that they can reinforce themselves if historical characteristics influence how individuals shape their preferences and make their choices.

Alternatively, gender differences in labor market outcomes may be associated to discrimination. With respect to that, there are two main economic models: (i) taste-based discrimination, in which members of a majority group discriminate against a minority group based on their "taste"; and (ii) statistical discrimination, which occurs when employers are imperfectly informed about the characteristics of a member of a minority and "statistically discriminate" based on the characteristics of this minority. A third model that combines some of the factors described above is the model of occupational exclusion.

${ }^{1}$ For example, the wage gap in Denmark in 2010 was 20\% (3) and in the US in 2007, it was $29 \%$ (4), compared to a gap of $26 \%$ in Brazil, in 2010 (author's calculation with Census data). 
It discusses the role of preferences, social norms, human capital accumulation and discrimination in determining the occupational segregation - the fact that women and men tend to work in different occupations.

In this paper, I explore this fact that the distribution of genders across occupations is different to understand how an important economic shock affects gender inequality in the labor market. I do this by studying the impact of a trade-induced shock to local labor demand in Brazil. This shock was plausibly exogenous and provides an interesting empirical setting to study gender inequality in the labor market. First, because of the heterogeneity in its intensity across Brazilian local economies. Second, because it was not gender neutral, as industries with a higher share of women employed was those with greater tariff cuts. Thus, this trade shock changed labor market conditions in a way that may have had consequences for gender inequality.

In late 1980's and early 1990's, Brazil experienced a trade liberalization that eliminated non-tariff barriers of the importing policy and led to a substantial reduction in import tariffs. The empirical exercise of this paper explores the time variation in these tariffs, the variability of tariff changes across industries and the heterogeneity of productive specialization across regions (and, consequently, the distribution of workers between these industries in each of these regions) to construct a measure of "regional tariff change". I use this measure to link changes in labor market conditions to gender inequality. I study medium (1991-2000) and long (1991-2010) term effects of trade liberalization on labor market outcomes separately by gender. Besides that, I analyze potential implications of the shock for human capital accumulation and marital decisions.

Moreover, I extended the (6)'s model of occupational segregation to accommodate elastic labor supply. This extension permits to understand not only the reallocation of workers between sectors and the changes in gender wage gap in each of them, but also allows incorporating the movement of entry and exit of workers from employment. Thus, this model provides a conceptual framework to rationalize the empirical results, analyzing the mechanisms behind the changes in labor market outcomes related to the trade liberalization.

Results indicate that, in the medium run, there was an increase in the gender wage gap in the economy. In light of the model, I argue that this effect is due to a reallocation of women from tradables, a sector with lower wage gap, to the non-tradable sector, in which the gender wage gap is greater. This change was due to the reduction in the share of workers in the tradable sector, the most affected by liberalization, which the non-tradable sector was not able to fully compensate. In particular, the employment losses in the tradable sector 
were proportionally higher for women. This effect occurred because the share of women in this sector was lower. It is also possible that this effect occurred due to the comparative advantage men have in this sector. With this, there was a decrease in the share of women among the employed in the tradable sector.

As not all workers displaced from tradables were absorbed by the nontradable sector, there was a decrease in workers' employment in the medium run. This employment reduction was proportionally greater for women, implying in a decrease in the share of women among the employed. These employment losses ceased in the long run for women, while men experienced an increase in employment. However, there was still a decrease in the share of workers in the tradable sector with a new reduction in the share of women among the employed in this sector. In the non-tradable sector, there was an increase in the share of workers only for men in the long run. At the same time, the gender wage gap in the non-tradable sector reduced.

In addition, I investigated the effects of the trade liberalization on human capital accumulation and the marriage market. There was an increase in the years of schooling for men in the medium and long run, while for women this effect occurred only in the long run. I also find that the share of highschool graduates increased among the employed, in the workforce and in the population as a whole in both periods. Finally, there was a reduction associated to trade liberalization in the share of women that have children and are married in the medium and long run.

This paper contributes to the literature in the following aspects. First, I show how an important economic shock affected the gender inequality by changing conditions in the labor market. In particular, I show that the fact that the shock was not gender neutral had implications for the distribution of effects between women and men. Then, by analyzing the results in light of a conceptual model of occupational segregation, I provide empirical evidences of the importance of the distribution of women and men between occupations in determining the consequences of an economic shock to gender inequality, as noted by (7) and (8). Finally, I also provide evidences suggesting that these changes in the labor market had some impact in the marriage market and in the human capital accumulation.

This paper relates to three strands of literature. First, it contributes to a literature that aims to understand the distributional effects of trade liberalization (e.g., (9). See (10) for a review). More specifically, it is related to papers that explore the empirical approach proposed by (11), that uses the concept of local labor markets to analyze regional effects of a trade shock (see, 
for instance, $(12,13,14,15))$. In particular, I use "regional tariff change", a measure of trade-induced shock to local labor markets formalized by (16) in the context of Brazilian trade liberalization. This measure was already used by many other studies that analyze the consequences of the Brazilian trade liberalization on skill premium, wages, earnings, employment, mobility, informality, racial wage gap and crime (see $(17,1,18,2)$ ). In this paper, I use this measure to study the effects of Brazilian trade liberalization on gender inequality in the labor market.

Second, it is part of a broad literature of gender inequality that studies its causes and evolution. As already advocated in the literature, social rules and job aspects are important in influencing gender inequality in the labor market (see, for example, $(19,20,21,22)$ ). With respect to job aspects, studies also associate gender inequality in the labor market to career dynamics and its impact on the selection into occupations $(23,3)$. This paper contributes to this literature by providing more evidences of the role of social norms and job characteristics in determining the occupations in which women and men are, and its consequences for gender inequality.

Finally, this paper is related to an empirical literature that examines the relationship between trade (or globalization) and gender gap. This literature provides mixed evidences about the effects of trade on gender inequality. Some papers find that the gender gap decreases when firms face more competition from external market due to reduction in their ability to discriminate $(24,25)$ and that trade leads to greater losses for men due to heterogeneous mobility costs between genders (4). Another study finds evidence of improvement in women's wages and employment associated to trade due to technology update of new exporting firms (26). However, there are also evidences of positive association between wage discrimination against women and competition from foreign trade in concentrated industries due to a loss in women's bargain power (27).

This comes at no surprise, as (8) discusses that there are reasons why globalization may both narrow or increase gender wage gap. Among them, reduction in taste-based discrimination is one of the reasons for a possible decrease in the gap, while competition from trade may weaken women's bargain power and worsen the gender wage gap. He conducts a cross-country analysis of the impact of globalization on the gender wage gap within occupations and finds that in richer countries the gap tends to decrease with trade and FDI, but in poorer countries there is little evidence that trade and FDI reduce gender wage gap. These mixed evidences support the notion that the effect of trade on gender inequality depends on the structure of the labor market and how it 
is affected by the shock. This paper contributes to this literature by providing further evidences of the effects of trade on gender inequality.

Lastly, (28) analyze the effects of Brazilian trade liberalization on gender differences in labor force participation, employment rates and sectoral reallocation. They find that both women and men experienced reduction in participation and employment rates in harder-hit regions, with greater effects on male's level of employment, but equal effect in proportionate terms. My paper contributes to their study by also analyzing the effects of the trade liberalization on the wage gap, an important margin of adjustment in the shock aftermath. Besides that, I show in the results section that the absence of pre-existing trends in their empirical estimation compromises part of their finds. Finally, I provide a conceptual model capable of rationalizing the results, which shows the consequences of occupational segregation on gender inequality in face of an economic shock.

The remainder of the paper is organized as follows: the next section presents the Brazilian trade liberalization episode. Section 3 provides information of the data sources and presents descriptive statistics. In section 4 I discuss the empirical strategy and present a conceptual framework to rationalize the results, which are shown in section 5 . Section 6 concludes. 


\section{2}

\section{The Trade Liberalization in Brazil}

(29) describe that, until the end of the 1980s, the Brazilian import policy only allowed the entry of goods with no national equivalent or to cover excess demand. It used not only redundant import tariffs, but also additional taxes and non-tariff barriers such as imports limits and lists of banned products, and 42 special regimes reducing or exempting tariffs. Beginning in 1988, the government started a change in the import policy with the aim to induce a better allocative efficiency of resources through external competition. This led to changes in a tariff structure based, with few changes, on the rates established in 1957. The changes occurred in three rounds (1988-1989; 1990-1993; and 1994).

In the 1988-1989 period, there was a tariff reduction, but tariff redundancy remained almost unchanged, some additional taxes ${ }^{1}$ were extinguished and special regimes were partially eliminated. However, there was no significant effect on the level of protection. In March 1990, the new government eliminated lists of banned products and special regimes. From June onwards, import tariffs became the main instrument of imports policy and were gradually reduced until the end of 1993. In 1994, the trade liberalization was intensified in order to help the stabilization plan and there was a reduction of import tax rate in anticipation of Mercosul's ${ }^{2}$ common external tariff implementation.

In the following years, tariffs were essentially stable. Therefore, the changes occurred between 1990 and 1995 are a good representation of trade liberalization. ${ }^{3}$ In this period, there was a reduction in 17.7 percentage points in the average nominal tariff, from $30.5 \%$ to $12.8 \%$, and in 7.5 percentage points in the standard deviation, from $14.9 \%$ to $7.4 \%$. This means that not only the average tariff reduced, but there was also a decrease in tariff dispersion. Besides that, tariffs ranged from 0 to 41 percent, almost reaching

${ }^{1}$ For example, tax on credit, foreign exchange and insurance (IOF, in the acronym in Portuguese).

${ }^{2}$ South Common Market, a trade agreement initially signed in 1991 by Argentina, Brazil, Paraguay e Uruguay.

${ }^{3}(2)$ show that tariff changes between 1990 and 1995 are highly correlated with changes between 1990-2000 and 1990-2010, implying that using this period well represent the permanent shock. 
the initial government goal of being between $0 \%$ and $40 \%$. Figure 2.1 shows the approximate percentage change of tariffs by industries.

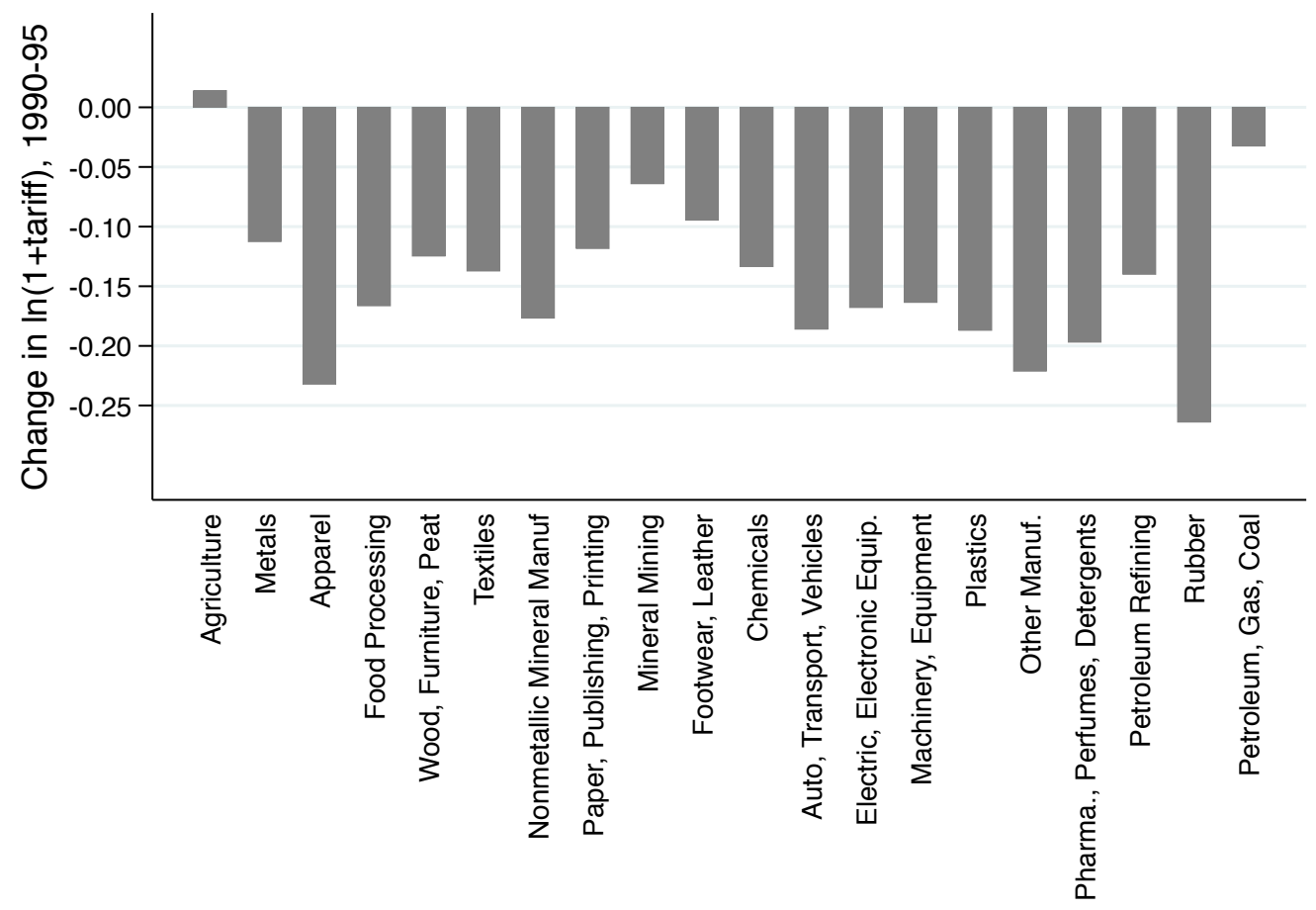

Changes in ln of 1 plus tariff, the same measure used in the empirical exercise.

Figure 2.1: Tariff Changes 1990-1995, (1)

I use tariff data from (29) to investigate the difference by gender of the effects of Brazilian trade liberalization on labor market outcomes in the medium and long run. The idea that this shock may have heterogeneous effects across genders comes from the distribution of women and men in affected industries. Note from Figure 2.2 that there is a negative association between the share of women in affected industries in 1991 (baseline) and the tariff change between 1990 and 1995 (even when I exclude the apparel sector (Figure A.1 in appendix)). This relation points that the shock was not gender neutral, as women were more concentrated in industries with greater tariff cuts. Many factors could generate different distributional effects across genders following a trade shock: the attachment of women to labor supply; workers and employers preferences; or, the types of occupation in which women are employed. For instance, (30) argues that women have higher mobility costs and less ability to arbitrage wage differentials in the shock aftermath. This paper explores the distribution of women across sectors and the gender wage differential in each of them to understand these heterogeneous effects between women and men.

As described above, changes in tariffs were part of a government program to promote competitiveness. The tariff cuts sought to equalize the level of tariffs 


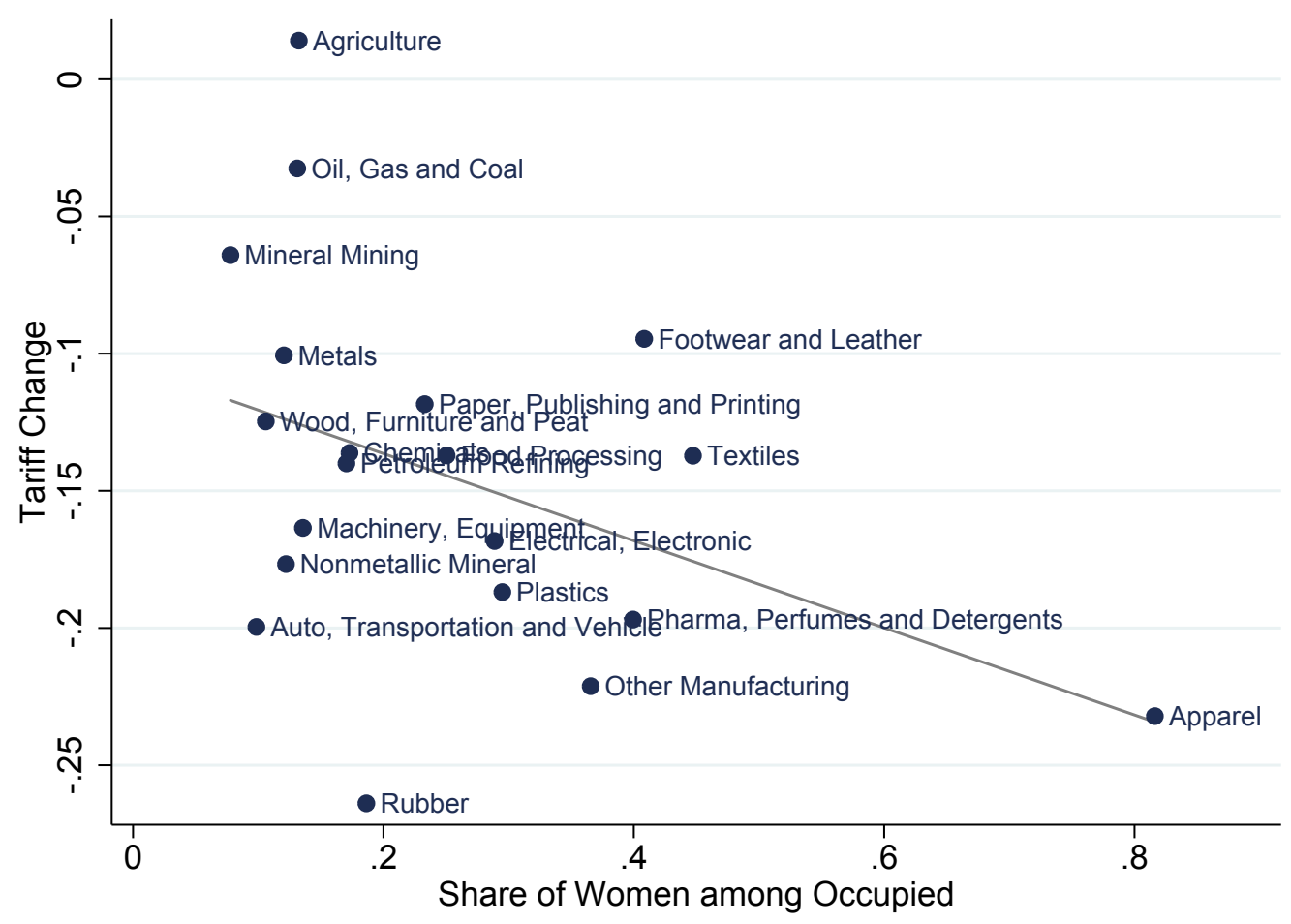

Figure 2.2: Share of Women across Industries

across sectors, i.e., the higher were the tariffs before liberalization, the greater was the tariff cut (see Figure 1 in (16)). Therefore, there is little concern that tariff changes were driven by private lobby associated to industries or regions, indicating that the shock is plausibly exogenous ${ }^{4}$.

\section{1}

\section{Regional Tariff Change}

The empirical exercise exploits changes in tariffs in each sector and the heterogeneity in the industrial specialization across local economies. Tariff data comes from (29), that detail yearly changes in nominal tariffs to main groups of activity using averages weighted by value added of each industry. The variable I use to represent the local economy shock was proposed by (16) and has been used in the literature to study the impact of Brazilian trade liberalization ${ }^{5}$. Behind this variable, there is a specific-factor model for each economy (here, the local economy is represented by the micro-region). There are many industries in each economy, which use two production inputs: one factor that is immobile between industries and regions and the other, labor, that is assumed to be immobile between regions, but mobile between industries. This model provides

${ }^{4}$ See $(10,16,17,1,2)$ for additional discussions

${ }^{5}$ See, for example, $(17,1,18,2)$. 
the rationale behind the relationship between the price changes due to trade liberalization and the local economies: although all regional economies face the same price changes across industries, the effect of these changes on each of them depends on its industry composition.

The regional tariff change, $R T C$, is constructed as follows:

$$
\begin{gathered}
R T C_{m}=\sum_{i \in T} \psi_{m i} \Delta \ln \left(1+\tau_{i}\right), \\
\text { where } \psi_{m i}=\frac{\frac{\lambda_{m i}}{\varphi_{i}}}{\sum_{j \in T} \frac{\lambda_{m j}}{\varphi_{j}}} .
\end{gathered}
$$

This variable is a weighted average of changes in tariffs between 1990 and 1995 for each micro-region $m$. In equation 2-1, $i$ and $j$ indexes industries in tradables, $T$, and $\tau_{i}$ is the tariff in industry $i$. Observe that the adjustment of tariff changes ideally aims to account for: ( $i$ ) the size of industry $i$ in the local economy and (ii) the elasticity of substitution between production factors in each industry, combined with the importance of non-labor production factor in its cost share. Thus, the weight $\psi_{m i}$ considers: first, the relevance of the employment in industry $i$ to the total employment in the microregion, $\lambda_{m i}=\frac{L_{m i}}{L_{m}}$, where $\lambda$ is calculated using 1991 census data; second, the labor demand elasticity. However, for this second adjustment, the absence of credible estimates of labor demand elasticity requires simplifying assumptions. Therefore, I assume Cobb-Douglas production function and suppose that the factor shares varies across industries but not between regions. So, $\varphi_{i}$ is measured as one minus wagebill share of industry value added according to national accounts (IBGE).

The regional tariff change does not include data on the non-tradable sector because its prices move together with traded prices, as shown by (16). This measure captures the heterogeneity in the trade shock, taking into account the importance of each industry to regional production (see Figure 3.1). Note that the $R T C$ is negative as it measures the tariff cuts. 


\section{Data}

I use four waves of the Brazilian Demographic Census - 1980, 1991, 2000 and 2010 - from the National Bureau of Statistics (IBGE). As the shock occurred between 1990 and 1995, I use 1991 as the baseline year and study medium and long-term effects with 2000 and 2010 censuses. The 1980 census serves as a control for previous trend in dependent variables. The unit of analysis is the micro-region, which consists of municipalities economically integrated with similar geographic and productive characteristics, representing the local labor market. There are 412 micro-regions compatible between 1980 and 2010 used in the empirical analysis. Figure 3.1 shows a map of the distribution of the RTC across the micro-regions. Lighter regions were the harder hit regions, but nearly all regions faced some tariff reduction. The analysis does not include Manaus free zone because it was already a free trade zone and faced no changes during the trade liberalization.

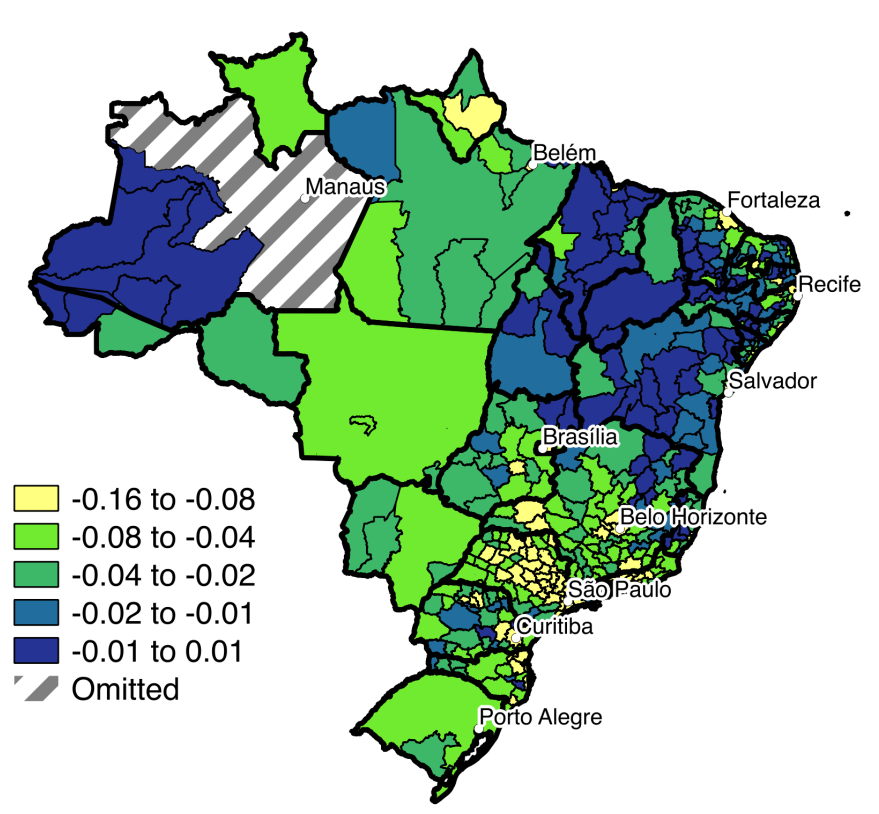

Figure 3.1: Regional Tariff Changes across Brazil, $R T C_{m},(2)$

I study the effects of trade on employment, wage inequality, distribution 
of employment across activity sectors by gender and schooling and marital decisions. For this, I use individual data of labor market outcomes and demographic characteristics to calculate means across local labor markets used as dependent variables in the second step of the estimation. To conduct the empirical analysis, I restrict the database to individuals between 18 and 64 years old and exclude those who are attending school.

Table 3.1 presents summary statistics of the main variables across microregions. Table 3.2 depicts statistics between tradables and non-tradables. We observe an increase in the years of schooling for both women and men, but men remained less educated than women. Women's participation rate sharply increased from 1991 to 2010, at the same time that men's participation decreased. This led to a growth in the share of women among those who were employed, even with the proportion of women in the population roughly constant. This increase was mainly driven by a growth in the share of women among workers in the tradable sector, but the share of women among the employed also increased in the non-tradable sector.

Over time, wages increased in the economy and the crude difference between genders decreased in both the tradables and non-tradables, but from 2000 to 2010 there was a little rise in the hourly wage difference in tradables, from 0.92 to 1.07 Brazilian Real. The conditional wage gap ${ }^{1}$ also decreased during this period, lowering the difference between tradables and non-tradables, but in the 2000-2010 interval there was a little reversal in the conditional wage gap reduction in non-tradables and in the economy as a whole.

\footnotetext{
${ }^{1}$ The wage gap after controlling for observable characteristics, estimated by mincerian regressions.
} 


\begin{tabular}{lccc}
\hline \hline & 1991 & 2000 & 2010 \\
\hline Share of Women in Population & 0.50 & 0.50 & 0.50 \\
& $(0.02)$ & $(0.02)$ & $(0.01)$ \\
Years of Schooling & & & \\
Women & 4.07 & 5.29 & 6.93 \\
& $(1.26)$ & $(1.31)$ & $(1.12)$ \\
Men & 3.83 & 4.85 & 6.23 \\
& $(1.52)$ & $(1.54)$ & $(1.34)$ \\
Participation Rate & & & \\
Women & 0.34 & 0.49 & 0.57 \\
& $(0.08)$ & $(0.08)$ & $(0.09)$ \\
Men & 0.92 & 0.87 & 0.83 \\
Share of Women among Occupied & 0.26 & 0.34 & 0.39 \\
& $(0.05)$ & $(0.04)$ & $(0.03)$ \\
Average Real Hourly Wage & & & \\
Women & 3.27 & 4.50 & 5.83 \\
& $(1.45)$ & $(1.48)$ & $(1.66)$ \\
Men & 4.28 & 5.44 & 6.75 \\
Mean Conditional Wage Gap & $(2.02)$ & $(2.24)$ & $(2.54)$ \\
& 0.40 & 0.24 & 0.26 \\
N. Obs. & $(0.20)$ & $(0.11)$ & $(0.09)$ \\
\hline \hline
\end{tabular}

Source: Census (IBGE). Standard deviations in parenthesis. Statistics are averages across micro-regions. Real wages are in $2010 \mathrm{R} \$$. Mean conditional wage gap is the average of the conditional gender wage gap, estimated by mincerian regressions at the micro-region level.

Table 3.1: Labor Market Summary Statistics across Micro-regions 


\begin{tabular}{lcccccc}
\hline \hline & \multicolumn{2}{c}{1991} & \multicolumn{2}{c}{2000} & \multicolumn{2}{c}{2010} \\
\hline \multirow{2}{*}{ Share of Women } & Trad. & Nontrad. & Trad. & Nontrad. & Trad. & Nontrad. \\
& 0.14 & 0.40 & 0.23 & 0.43 & 0.29 & 0.46 \\
Average Real Hourly Wage & $(0.07)$ & $(0.05)$ & $(0.07)$ & $(0.03)$ & $(0.07)$ & $(0.03)$ \\
Women & & & & & & \\
& 2.16 & 3.70 & 3.23 & 4.85 & 4.31 & 6.19 \\
Men & $(1.56)$ & $(1.44)$ & $(1.51)$ & $(1.50)$ & $(1.90)$ & $(1.56)$ \\
& 3.36 & 5.66 & 4.15 & 6.61 & 5.38 & 7.63 \\
Mean Conditional Wage Gap & $(1.93)$ & $(1.83)$ & $(2.11)$ & $(2.15)$ & $(3.07)$ & $(2.41)$ \\
& 0.33 & 0.40 & 0.25 & 0.21 & 0.22 & 0.26 \\
N. Obs. & $(0.22)$ & $(0.20)$ & $(0.16)$ & $(0.11)$ & $(0.15)$ & $(0.07)$ \\
\hline \hline
\end{tabular}

Source: Census (IBGE). Standard deviations in parenthesis. Statistics are averages across micro-regions. Real wages are in $2010 \mathrm{R} \$$. Mean conditional wage gap is the average of the conditional gender wage gap, estimated by mincerian regressions at the micro-region level.

Table 3.2: Distribution of Labor Market Outcomes across Tradables and Nontradables 


\section{4}

\section{Empirical Strategy}

In this section I explain the empirical approach and the conceptual framework that I use to rationalize the results. This paper seeks to investigate the distribution between men and women of the effects of trade liberalization on the labor market. I do this in two steps: first, I calculate averages of outcomes of interest for each year and micro-region and, then, I proceed with a regression to understand the effect of the regional tariff change on those variables.

The empirical strategy benefits from the variability of tariff changes across industries and the distribution of employment among these industries across the country regions. The local labor market concept was already used by (31) to study the association between foreign competition and returns to education in US. However, the approach used here was first proposed by (11) to investigate the effects of Indian trade reform on poverty and inequality. This approach contrast local economies more and less affected by the trade liberalization ${ }^{1}$. I follow (16)'s formalization of this approach for Brazil, which has been extensively used in the literature ${ }^{2}$. The logic is that each local economy suffers a shock according to labor market and productive characteristics. The exercise explores the different intensities in these changes across regions.

The identifying assumption is that the shock is exogenous to local economic conditions and orthogonal to other determinants of gender inequality in the local economies omitted in the analysis. I argue this is a plausible assumption because to threat the identifying strategy (that is, for RTC not to be exogenous), other institutional factors should simultaneously (i) affect women and men in different ways and (ii) be correlated with $R T C$, i.e., affect gender inequality in the same way that $R T C$ do. Of course, institutional factors affect genders differently, but they would need be changing and affecting workers distribution across industries in the same way of the tariff changes. But the variation in tariffs was caused by a change in the government import policy that sought to open the economy to foster competitiveness and increase productive efficiency. Thereby, changes attempted to uniform tariffs across

${ }^{1}$ See $(12,13,14,15)$ for applications of this methodology.

${ }^{2}$ See $(17,1,2,18)$. 
industries, as discussed in section 2, instead of caused by private lobby from industries or local economies. That said, this seems to be a reasonable hypothesis. Moreover, the literature already broadly discussed the hypothesis of exogeneity of these tariff changes ${ }^{3}$.

\section{1}

\section{First Step}

The first step of the analysis consists in calculating for each census year the average of the variables of interest for all micro-regions. There are two sets of variables: for the first, I only calculate the variables' average; for the other set - wages -, the demographic dimension is relevant in determining the differences across individuals. Thus, to circumvent the effect of possible changes in individuals characteristics and the return to them, I follow (16) and estimate mincerian regressions by Ordinary Least Squares, controlling for individuals' demographic and productive characteristics in order to obtain the conditional gender wage gap - the remuneration men receive that is unexplained by observables. The estimated equation is:

$$
\ln \left(\text { wage }_{i m t}\right)=\gamma_{m t} \text { male }_{i m t}+\theta_{m t}+\pi_{m t} X_{i m t}+\epsilon_{i m t}
$$

where $i$ indexes individuals, $m$ represents the micro-region and $t$ the census year. wage is the worker's hourly wage, male $e_{i m t}$ is an interaction between an indicator of male gender and a micro-region indicator, $\theta$ is a micro-region fixedeffect and $X$ includes age and age squared, to account for worker's experience, indicators for each year of education and for great sectoral groups ${ }^{4}$ and dummies if the worker is white, married, have children and live in urban area. I save the estimated coefficient $\hat{\gamma}_{m t}$, the conditional wage gap, to use in the second step.

\section{2}

\section{Second Step}

The objective in this step is to study the impact of liberalization on gender inequality. I do this by estimating equation 4-2:

$$
\Delta_{91, t^{\prime}} y_{m}=\alpha+\beta R T C_{m}+\theta_{s}+\rho y_{m 80}+\phi W_{m 91}+\varepsilon_{m}
$$

where $\Delta_{91, t^{\prime}} y_{m}$ is the difference between 1991 and $t^{\prime}=2000,2010$ (medium and long-term effects) of the outcome of interest - in the case of conditional wage

${ }^{3}$ See $(17,1,2)$, for example

${ }^{4}$ As in (30), I use the following sectors: 1 - Agriculture and Mining; 2 - Low Tech Manufacturing; 3 - High Tech Manufacturing; 4 - Construction; 5 - Trade (Retail); 6 Transportation, Utilities and Communications; 7 - Services; and, 8 - Others. 
gap, $y_{m}$ is the $\hat{\gamma}_{m}$, from equation $4-1-$ and $\theta_{s}$ is a state fixed-effect. I estimate equation 4-2 by Weighted Least Squares. In the case of the conditional wage gap, I adjust for the fact that the dependent variable is estimated using the inverse of first step standard errors as weights. For the other set of variables, weights are the average population between the years under analysis. Standard errors are clustered by meso-regions (groups of micro-regions) to account for potential spatial correlation across regions.

The identifying assumption is that tariff changes only influence gender inequality in the labor market directly and are orthogonal to other determinants of inequality contained in the error term, $\varepsilon_{m}$. That is, they are exogenous with respect to local labor market conditions. There are two possible threats to this hypothesis, biasing the estimated $\beta$ : (i) $R T C$ is correlated to previous trends in the dependent variable; and (ii) $R T C$ correlates with other factors that determine the outcome variables. To account for (i), I include the 1980's level of the dependent variable in the first difference, $y_{m 80}$. This allows to control for different trends. To minimize concerns in (ii), I include a set of variables in the baseline year, $W_{m 91}$. First, I add the share of population that has complete high school, as a more educated population tends to have higher levels of participation and employment. I also add the share of women employed to account for the fact that regions where more women participate in the workforce possibly experienced a more intense shock, as the share of women employed is larger in industries with greater tariff cuts. Another factor that could influence women's labor supply and, consequently, differences between genders is marriage. Thus, I include in equation 4-2 the share of married women as a control. Finally, the distribution of women across educational groups is probably a factor determining the supply and demand for women's labor services and its allocation across sectors. So, this is a potential confounding factor. I handle this by including the share of women in four educational groups: less then 8 years of schooling (at most primary education), between eight and ten years (less than high school), between 11 and 14 years (high school and college drop-outs), and 15 years of schooling or more (at least college).

In this paper, I analyze the effects of trade liberalization for two sets of variables. First, I study labor market effects, for which the dependent variables are: participation and occupation rates, the share of women among occupied, the share of workers in the tradable and non-tradable sectors, the proportion of women in those sectors and the conditional wage gap in the economy as a whole and separated by tradables and non-tradables. For this group, I develop in section 4.3 a conceptual model that organizes the results relative to the labor market and provides intuition about the mechanisms at work. Then, 
I provide evidences of possible consequences of the labor market changes to other dimensions, namely, human capital accumulation and marriage market. In this case, the variables of study are: the share of high-school graduates in the population, in the workforce and among those employed, years of schooling, the share of married women and the share of women that have children.

\section{3}

\section{Conceptual Framework}

The literature has already shown that regions more affected by the Brazilian 1990's trade liberalization suffered deterioration in labor market outcomes in relation to those suffering a less intense shock, with relative losses in wages and employment, besides workers reallocation across productive sectors. These effects were worse in the medium run, but some also persisted in the long run. In this section I propose a conceptual model to rationalize the labor market effects of trade liberalization and the differences between women and men. To do that, I closely follow the model of occupational segregation presented in (6), but I relax the hypothesis of inelastic labor supply, which allows me to characterize participation and occupation rates, that are important dimensions of adjustment following the trade shock. Another difference from this model to (6) is that I use sectors, instead of occupations, to study gender segregation. I analyze the consequences of segregation of workers to the distribution of labor market outcomes between groups and discuss some implications of Brazilian 1990's trade liberalization. I assume that each local economy behaves as described below.

The idea of the model of occupational segregation is to analyze why women and men allocate themselves differently between occupations. First, workers may have distinct preferences about the characteristics of occupations, such as hours flexibility or family friendly jobs, and their distribution across occupations depends on these preferences. Alternatively, it is possible that employers in each occupation choose to hire women and men in different proportions depending on the costs they face. Additionally, if there are social characteristics that determine different expectations about women and men, then there may exist occupational segregation. Finally, men and women possibly make different choices relative to human capital accumulation, what influences the type of occupation they will work.

Suppose there are two types of workers in the economy, indexed by $g=f, m$. They choose between three statuses/sectors in the labor market, indexed by $s$ : tradables, $t$, non-tradables, $n$, and residual sector, $r$, representing unemployment and out of labor force. Total labor (in equivalent units) in sector 
$s$ is given by:

$$
N_{s}=L_{m s}+\mu_{s} L_{f s}
$$

where $\mu_{s}$ denotes the productivity of women relative to men in status $s$. This productivity may be related to the kind of activity performed in the occupations of each sector (for example, (26) argue that women and men have different skills and women are less productive in physically demanding activities relative to men). Men have comparative advantage in the tradable sector, $\mu_{t}<\mu_{n}$ and $\mu_{t}<1$. The marginal product of labor is given by $G_{t}\left(N_{t}\right)$ and $G_{n}\left(N_{n}\right)$.

Assume there is a "tax" to employers when hiring female workers that varies across sectors: $\tau_{t}^{w}, \tau_{n}^{w}$. This tax can be thought of as the taste for discrimination as in (32) and implies the following demand equilibrium condition:

$$
\begin{aligned}
w_{m t}=G_{t} & \text { and } \quad w_{m n}=G_{n} \\
w_{f t}=\left(1-\tau_{t}^{w}\right) \mu_{t} G_{t} & \text { and } \quad w_{f n}=\left(1-\tau_{n}^{w}\right) \mu_{n} G_{n} .
\end{aligned}
$$

Note, from 4-4, that the effects of $\tau_{s}$ and $\mu_{s}$ are not separable.

Because women and men can choose not to work, we have the supply condition, depending on the reservation wage:

$$
\begin{gathered}
w_{m t}, w_{m n} \geq \bar{w}_{m} \\
w_{f t}, w_{f n} \geq \bar{w}_{f} .
\end{gathered}
$$

We have, for each gender, the working age population:

$$
L_{g}=L_{g t}+L_{g n}+L_{g r}
$$

and the occupation rate can be written as:

$$
L_{g}^{O R}=L_{g}-L_{g r}=L_{g t}+L_{g n}
$$

To close the model, relative labor supply of workers in tradables and non-tradables is given by:

$$
\frac{L_{g t}}{L_{g n}}=X_{g} \theta_{g} \psi_{g}\left(\frac{w_{g t}}{w_{g n}}, \bar{w}_{g}\right)
$$

where $\psi($.$) is an ad hoc function that associates the relative supply to relative$ wages and the workers' reservation wage. It is increasing in the first argument, while the second argument shifts the function. The relative labor supply also depends on social characteristics, $X_{g}$, that determine the net benefit of working in sector $t$ for gender $g$. These characteristics may be social norms that influence people to choose the tradable sector or institutional constraints that limits or incentives the workers' access to the sector $t$. $\frac{L_{g t}}{L_{g n}}$ is also a function of workers' taste parameter, $\theta_{g}$, associated to job characteristics, such as a 
family-friendly environment. Similarly to $\tau$ and $\mu$, I cannot separately identify the effects from $X_{g}$ and $\theta_{g}$.

The labor demand conditions (equation 4-4) imply the wage ratios:

$$
\frac{w_{m t}}{w_{m n}}=\frac{G_{t}\left(N_{t}\right)}{G_{n}\left(N_{n}\right)}, \quad \frac{w_{f t}}{w_{f n}}=\frac{\left(1-\tau_{t}^{w}\right) \mu_{t} G_{t}\left(N_{t}\right)}{\left(1-\tau_{n}^{w}\right) \mu_{n} G_{n}\left(N_{n}\right)} .
$$

Combining equations 4-3, 4-7 and the relative labor supply gives:

$$
\begin{array}{r}
N_{t}=\frac{L_{m}^{O R} X_{m} \theta_{m} \psi_{m}\left(\frac{w_{m t}}{w_{m n}}, \bar{w}_{m}\right)}{1+X_{m} \theta_{m} \psi_{m}\left(\frac{w_{m t}}{w_{m n}}, \bar{w}_{m}\right)}+\mu_{t} \frac{L_{f}^{O R} X_{f} \theta_{f} \psi_{f}\left(\frac{w_{f t}}{w_{f n}}, \bar{w}_{f}\right)}{1+X_{f} \theta_{f} \psi_{f}\left(\frac{w_{f t}}{w_{f n}}, \bar{w}_{f}\right)} \\
N_{n}=\frac{L_{m}^{O R}}{1+X_{m} \theta_{m} \psi_{m}\left(\frac{w_{m t}}{w_{m n}}, \bar{w}_{m}\right)}+\mu_{n} \frac{L_{f}^{O R}}{1+X_{f} \theta_{f} \psi_{f}\left(\frac{w_{f t}}{w_{f n}}, \bar{w}_{f}\right)}
\end{array}
$$

Equations 4-9 and 4-10 determine the relative labor supply and relative wages in equilibrium. Equations 4-7 and 4-8 combined give the proportion of workers of gender $g$ in tradables:

$$
P_{g t}=\frac{L_{g t}}{L_{g}^{O R}}=\frac{X_{g} \theta_{g} \psi_{g}\left(\frac{w_{g t}}{w_{g n}}, \bar{w}_{g}\right)}{1+X_{g} \theta_{g} \psi_{g}\left(\frac{w_{g t}}{w_{g n}}, \bar{w}_{g}\right)}
$$

Equation 4-11 illustrates the direct and indirect relationship of the distribution of workers across sectors with parameters. This equation and the relative labor supply (equation 4-8) guide the interpretation of the empirical results in relation to the distribution of workers across tradables and nontradables.

Finally, from equation 4-4 we can characterize the gender wage gap in each sector:

$$
\begin{aligned}
\frac{w_{m t}}{w_{f t}} & =\left[\left(1-\tau_{t}^{w}\right) \mu_{t}\right]^{-1} \\
\frac{w_{m n}}{w_{f n}} & =\left[\left(1-\tau_{n}^{w}\right) \mu_{n}\right]^{-1}
\end{aligned}
$$

and the wage gap for the whole economy:

$$
\frac{w_{m}}{w_{f}}=\frac{\left(L_{m t} G_{t}+L_{m n} G_{n}\right) / L_{m}^{O R}}{\left[L_{f t}\left(1-\tau_{t}^{w}\right) \mu_{t} G_{t}+L_{f n}\left(1-\tau_{n}^{w}\right) \mu_{n} G_{n}\right] / L_{f}^{O R}} .
$$

Taking $\log$ of equation $4-12$, we get:

$$
\log w_{m s}-\log w_{f s}=-\left[\log \left(1-\tau_{s}^{w}\right)+\log \mu_{s}\right], \text { where } s=t, n .
$$


Note that the arguments of the logarithm functions at the right hand side of equation 4-14 are at most equal to one, thus the value in brackets is less than or equal to zero and $\left(\log w_{m s}-\log w_{f s}\right) \geq 0$. This equation helps us to interpret the results of the conditional wage gap in each sector and clarifies the relationship between the wage gap and the parameters: as the taste-based discrimination decreases to zero $\left(\tau_{s} \downarrow\right)$ and the relative productivity increases to one $\left(\mu_{s} \uparrow\right)$, the wage gap decreases.

The model illustrates that differences between women and men in each sector will depend on social norms, $X_{g}$, preferences, $\theta_{g}$, taste-based discrimination, $\tau_{s}^{w}$ and relative productivity, $\mu_{s}$. We observe in the data that men are more typically employed in tradables, while women are encountered more frequently in the sector that produces non-tradable goods. This pattern can be associated to: (i) social characteristics inducing women to non-tradables and men to tradables, independent of productivity, if $X_{f}<1$ and $X_{m}>1$; (ii) a comparative advantage of men in that occupation, if $\mu_{n}>\mu_{t}$ and $\mu_{t}<1$; (iii) a lower preference of women for this sector, $\theta_{f}<\theta_{m}$; or (iv) even by a greater discrimination in tradables, in which case $\tau_{t}^{w}>\tau_{n}^{w}$.

\subsection{1 \\ Comparative Static}

As each local economy specializes in the production of different goods, the distribution of industries will be diverse. Likewise, the workers' distribution across occupations will be distinct between local economies. Thus, these local economies will be subject to a more or less intense trade shock. As a result, changes in parameters will be different, as well as changes over time. Hence, in light of the model, there are four channels through which trade liberalization could affect gender inequality: $(i)$ with respect to wages, they are the relative productivity and the employers taste-based discrimination; and (ii) relative to workers distribution between sectors, social norms and workers' preferences about job characteristics are the possible channels.

For the first set of parameters, changes could occur if employers in regions more affected by the shock face more competition, which would lead to a decrease in discrimination, $\tau_{s}$. It could also occur if the trade openness modifies the competition faced by the workers in the labor market in different ways for women and men, which could change the relative productivity of them, $\mu_{s}$. For example, if low-skilled women were more pushed out of employment than highskilled women and men in both skill levels, there would be more skilled women employed in both sectors, which would increase their relative productivity to men. 
For the second group of parameters, changes would come from modifications in social norms associated to workers reallocation across sectors in the shock aftermath, weakening or reinforcing stereotypes such as "women's job" or "men's job". Alternatively, it could come from changes in workers' preference if the shock deteriorates job conditions in some sector. Relative to social norms, it is possible that the shock pushes more men to non-tradables, if the tradable sector experiences larger job losses, dissociating this sector to "women's job". However, as men have comparative advantage in tradables, the shock could also lead to further reduction of women in this sector, reinforcing stigma "men's job". Finally, with respect to job characteristics, the liberalization could worsen conditions in the tradable sector, for example, transforming it into a less friendly sector, leading workers to prefer the non-tradable sector. 


\section{Results}

In this section, I present estimates of the effect of the regional tariff change on labor market outcomes and also explore possible implications of these effects on individuals human capital accumulation and the marriage market. Note throughout the analysis that as $R T C$ is negative, we need to change the coefficient signal to interpret the effect of $R T C$ on the dependent variables.

\section{1}

\section{Labor Market Effects}

I start the analysis by looking at the effects of trade liberalization on the conditional wage gap. As described in section 4.3, there are social and individual characteristics that may lead to differences in labor market outcomes between women and men. In the model, employers taste-based discrimination, $\tau_{s}^{w}$, and the productivity ratio, $\mu_{s}$, are responsible for wage differences. Because these parameters are not observable and represent the unexplained part of the wage differences, I run mincerian regressions, controlling for observables, and use the estimated coefficient of a gender dummy, $\hat{\gamma}_{m t}$, as dependent variable in the second step of estimation, which captures the effects of the parameters $\mu_{s}$ and $\tau_{s}^{w}$ combined. I call this coefficient conditional wage gap.

Table 5.1 presents the results for this conditional wage gap for the whole economy and separating between tradables and non-tradables. In column (1), I show results of an unweighted regression with no state fixed effects. Panel A shows a negative effect of the regional tariff change on the mediumterm variation of the wage gap. This means that regions with greater tariff cuts exhibit an increase in the wage gap (or a lower decrease). When I include weights, in column (2), and add state fixed effects, in column (3), the magnitude and significance of the coefficient decrease, being significant only at ten percent. This result means that if a region was taken from the 90th to the 10th percentile of RTC, suffering a 0.11 log-point tariff cut, the conditional gender wage gap would increase by 0.037 log-point, which represents an increase of nearly $10 \%$ relative to initial wage gap.

At the same time that we observe RTC increasing the conditional wage 


\begin{tabular}{|c|c|c|c|c|c|}
\hline Dependent Variable & $\begin{array}{c}(1) \\
\Delta \hat{\gamma}_{m} \\
\end{array}$ & $\begin{array}{l}\text { Overall } \\
\quad(2) \\
\Delta \hat{\gamma}_{m} \\
\end{array}$ & $\begin{array}{c}(3) \\
\Delta \hat{\gamma}_{m} \\
\end{array}$ & $\begin{array}{c}\text { Tradables } \\
\qquad(4) \\
\Delta \hat{\gamma}_{m} \\
\end{array}$ & $\begin{array}{c}\text { Nontradables } \\
(5) \\
\Delta \hat{\gamma}_{m} \\
\end{array}$ \\
\hline \multicolumn{6}{|c|}{ Panel A: Medium-term (1991-2000) } \\
\hline RTC & $\begin{array}{c}-1.142^{* * *} \\
(0.356)\end{array}$ & $\begin{array}{l}-0.361 \\
(0.252)\end{array}$ & $\begin{array}{c}-0.349^{*} \\
(0.187)\end{array}$ & $\begin{array}{c}-0.0423 \\
(0.143)\end{array}$ & $\begin{array}{l}-0.265 \\
(0.169)\end{array}$ \\
\hline Observations & 412 & 412 & 412 & 403 & 412 \\
\hline R-squared & 0.449 & 0.413 & 0.664 & 0.167 & 0.724 \\
\hline State FE & No & No & Yes & Yes & Yes \\
\hline \multicolumn{6}{|c|}{ Panel B: Long-term (1991-2010) } \\
\hline RTC & $\begin{array}{l}-0.411 \\
(0.372)\end{array}$ & $\begin{array}{c}0.466 \\
(0.316)\end{array}$ & $\begin{array}{c}0.151 \\
(0.207)\end{array}$ & $\begin{array}{c}0.00964 \\
(0.237)\end{array}$ & $\begin{array}{c}0.398 * * \\
(0.169)\end{array}$ \\
\hline Observations & 412 & 412 & 412 & 403 & 412 \\
\hline R-squared & 0.401 & 0.424 & 0.732 & 0.433 & 0.777 \\
\hline State FE & No & No & Yes & Yes & Yes \\
\hline
\end{tabular}

Source: IBGE Census. Standard errors (in parentheses) are clustered by mesoregions. *** $\mathrm{p}<0.01,{ }^{* *} \mathrm{p}<0.05,{ }^{*} \mathrm{p}<0.1$. All regressions include 1980's level of dependent variable as control. Column (1) is an unweighted regression. All other columns are regressions weighted by the inverse of first step standard errors. Number of observations in column (4) is 403 because for some years and micro-regions there is no women in tradables sector.

\section{Table 5.1: Conditional Wage Gap}

gap in the economy as a whole, there is no significant effect on tradables and non-tradables in the medium run (columns (4) and (5) of Panel A). Given the model, this result would imply constant taste-based discrimination, $\tau_{s}^{w}$, and relative productivity, $\mu_{s}$, in this period (recall the wage gap from equation 4-12).

$$
\begin{aligned}
\frac{w_{m t}}{w_{f t}} & =\left[\left(1-\tau_{t}^{w}\right) \mu_{t}\right]^{-1} \\
\frac{w_{m n}}{w_{f n}} & =\left[\left(1-\tau_{n}^{w}\right) \mu_{n}\right]^{-1}
\end{aligned}
$$

But from equation 4-13, we can approximate the decomposition of changes in the wage gap of the economy in changes of sectoral wage gap, in the distribution of workers between these sectors and changes in occupation rate. 


$$
\begin{aligned}
\Delta\left(\frac{w_{m}}{w_{f}}\right) & =\left[\frac{\left(\Delta\left(L_{m t}\right) G_{t}+\Delta\left(L_{m n}\right) G_{n}\right) / \Delta\left(L_{m}^{O R}\right)}{\left[\Delta\left(L_{f t}\right)\left(1-\tau_{t}^{w}\right) \mu_{t} G_{t}+\Delta\left(L_{f n}\right)\left(1-\tau_{n}^{w}\right) \mu_{n} G_{n}\right] / \Delta\left(L_{f}^{O R}\right)}\right] \\
& +\left[\frac{\left(L_{m t} \Delta\left(G_{t}\right)+L_{m n} \Delta\left(G_{n}\right)\right) / L_{m}^{O R}}{\left[L_{f t} \Delta\left(\left(1-\tau_{t}^{w}\right) \mu_{t} G_{t}\right)+L_{f n} \Delta\left(\left(1-\tau_{n}^{w}\right) \mu_{n} G_{n}\right)\right] / L_{f}^{O R}}\right]
\end{aligned}
$$

We can see that the change in $\frac{w_{m}}{w_{f}}$ is coming from workers distribution across sectors and changes in the occupation rate looking at Tables 5.2 and 5.5. The dependent variables of Table 5.2 are the share of employees in tradables and non-tradables over the working age population. Columns (1), (3) and (5) show the medium-term effects of the RTC on the share of workers employed in tradables (Panel A) and non-tradables (Panel B), for all workers, women and men, respectively. We observe a decrease in the share of workers in tradables $\left(\Delta\left(L_{f t} / L_{f}^{O R}\right), \Delta\left(L_{m t} / L_{m}^{O R}\right)<0\right)$, with non-tradables partially offsetting these losses $\left(\Delta\left(L_{f n} / L_{f}^{O R}\right), \Delta\left(L_{m n} / L_{m}^{O R}\right)>0\right)$. The proportional effects for women and men are in line with those encountered by (28), although the magnitude of coefficients are not comparable as they estimate the effects in log. As the conditional wage gap in tradables is, on average, lower than in non-tradables (0.33 versus 0.40 in 1991), a decrease in the share of women employed in tradables, associated with an increase in non-tradables imply this negative effect on overall wage gap. Table 5.3 summarizes this effects.

The decline in the share of workers in tradables is consistent with a reduction in the demand for goods produced by firms in this sector due to the trade shock which induces a contraction in labor demand, $N_{t}$. As the share of women employed in this sector is lower than men's share, $L_{f t}<L_{m t}$, the proportional effect is greater for women. This effect also occurs if we have relative productivity, $\mu_{t}$, lower than unity, as employers will choose to reduce women's labor services to increase productivity when facing the shock. As women faced a larger reduction in tradables employment in proportional terms, the share of women in tradables decreased in the medium run (Column (1) of Table 5.4), that is, the proportion of women among all employees in the tradable sector decreased.

This demand shock generates a reallocation, with the non-tradable sector absorbing part of workers displaced from the tradable sector. This effect is consistent with a drop in wage ratio of tradables relative to non-tradables associated with the price cut produced by trade liberalization and is in line with what (1) find. This effect could also occur if the adverse shock in tradables causes a reduction in workers preference to work in this sector, $\theta_{g}$, what would lead to an increase in the number of workers in non-tradables relative to 


\begin{tabular}{|c|c|c|c|c|c|c|}
\hline \multirow[b]{3}{*}{ Dependent Variable } & (1) & $(2)$ & $(3)$ & (4) & $(5)$ & $(6)$ \\
\hline & \multicolumn{2}{|c|}{ Overall } & \multicolumn{2}{|c|}{ Women } & \multicolumn{2}{|c|}{ Men } \\
\hline & $\Delta_{00-91}$ & $\Delta_{10-91}$ & $\Delta_{00-91}$ & $\Delta_{10-91}$ & $\Delta_{00-91}$ & $\Delta_{10-91}$ \\
\hline \multicolumn{7}{|l|}{ Panel A: Tradables } \\
\hline RTC & $\begin{array}{c}0.794^{* * *} \\
(0.0979)\end{array}$ & $\begin{array}{c}0.726^{* * *} \\
(0.112)\end{array}$ & $\begin{array}{c}0.430^{* * *} \\
(0.0890)\end{array}$ & $\begin{array}{c}0.499^{* * *} \\
(0.0924)\end{array}$ & $\begin{array}{c}1.179^{* * *} \\
(0.119)\end{array}$ & $\begin{array}{c}0.991^{* * *} \\
(0.142)\end{array}$ \\
\hline Observations & 412 & 412 & 412 & 412 & 412 & 412 \\
\hline R-squared & 0.822 & 0.821 & 0.673 & 0.709 & 0.841 & 0.847 \\
\hline State FE & Yes & Yes & Yes & Yes & Yes & Yes \\
\hline \multicolumn{7}{|c|}{ Panel B: Nontradables } \\
\hline RTC & $\begin{array}{c}-0.203^{* * *} \\
(0.0417)\end{array}$ & $\begin{array}{l}-0.0934 \\
(0.0685)\end{array}$ & $\begin{array}{c}-0.118^{* *} \\
(0.0482)\end{array}$ & $\begin{array}{c}0.0260 \\
(0.0738)\end{array}$ & $\begin{array}{c}-0.258^{* * *} \\
(0.0672)\end{array}$ & $\begin{array}{c}-0.218^{* *} \\
(0.0977)\end{array}$ \\
\hline Observations & 412 & 412 & 412 & 412 & 412 & 412 \\
\hline R-squared & 0.796 & 0.662 & 0.700 & 0.814 & 0.820 & 0.805 \\
\hline State FE & Yes & Yes & Yes & Yes & Yes & Yes \\
\hline
\end{tabular}

Source: IBGE Census. Standard errors (in parentheses) are clustered by mesoregions. ${ }^{* * *}$ $\mathrm{p}<0.01,{ }^{* *} \mathrm{p}<0.05,{ }^{*} \mathrm{p}<0.1$. This is the share of employees in tradables and nontradables over the working age population. Tradables: agriculture and mining, low-tech and high-tech manufacturing; Nontradables: construction, trade (sales), transportation, utilities, communications and services. Controls include 1980's level of dependent variable; 1991's level of: share of high-skilled in the population; share of women employed in the population; share of married women; share of women among those with (i) less than $8 \mathrm{y}$ of schooling, (ii) between 8y and 10y of schooling, (iii) between 11 and 14 years of schooling,

(iv) more than 15 years of schooling. Regressions are weighted by average population between 1991 and 2000 or 1991 and 2010.

Table 5.2: Share of Tradables and Non-tradables

tradables, as can be seen in equation 5-2. In the non-tradable sector, the proportional effect is similar between men and women, in the medium run. Thus, there is no significant effect of the regional tariff change on the share of women in this sector (Column (3) of Table 5.4).

$$
\begin{aligned}
\frac{L_{f t}}{L_{f n}} & =X_{f} \theta_{f} \psi_{f}\left(\frac{w_{f t}}{w_{f n}}, \bar{w}_{f}\right) \\
\frac{L_{m t}}{L_{m n}} & =X_{m} \theta_{m} \psi_{m}\left(\frac{w_{m t}}{w_{m n}}, \bar{w}_{m}\right)
\end{aligned}
$$

Because the non-tradable sector was not capable to absorb all displaced workers, there was a reduction in the employment rate - the share of workers employed over the working age population - for both women and men, as columns (1) and (2) of Table 5.5 show. This effect was greater for women, who also experienced a decline in participation rate - the proportion of workers employed or searching for a job over the working age population - (column (1) of Table 5.6). As can be seen from equation 5-1, this greater decline in 


\begin{tabular}{lc}
\hline \hline & Medium term \\
\hline Conditional Wage Gap in Tradables & No effect \\
Conditional Wage Gap in Nontradables & No effect \\
Women in Tradables & Decrease \\
Women in Nontradables & Increase \\
\hline Conditional Wage Gap - Total & Increase \\
\hline \hline
\end{tabular}

Table 5.3: Summary of Medium-term Effects on Conditional Wage Gap

women's occupation rate also collaborated to increase the conditional wage gap observed in the medium run (column (3), Panel A, Table 5.1). These effects on employment and participation rates are similar to those encountered by (28), but they also find a reduction in participation for men and the effects for them are larger in both cases. One cause for these differences is the fact that they do not control for pre-existing trends, as they do not have access to 1980's census, what compromises their estimates, as 1980's level of dependent variable is significant in almost all specifications. But even when I do not include preexisting trends, the effects are greater for women, thus the differences between my paper and (28) are related to differences in the set of controls we include. Taken together, the previous results implied a decrease in the share of women among all workers employed in the medium run, as shown in Table 5.7. The coefficient of column (1) implies in a reduction of 1.29 percentage points in the share of women among those who are employed if we move a region from the 90th percentile to the 10th percentile of the RTC, a change of approximately -0.11 log-point.

I discussed above the medium-term effects of trade liberalization. Now, I analyze if the effects persisted in the long run or were reverted and examine possible explanations. In Panel B of Table 5.1, we see in column (3) that there is no significant effect of liberalization on conditional wage gap, that is, the medium-term effect dissipates in the long run. However, there is a positive effect of the regional tariff change on the wage gap of the non-tradable sector, i.e., harder hit regions experienced a decrease in the conditional wage gap in this sector, while the gap in tradables remained unaltered. Two factors could rationalize this effect. First, employers may have reduced their taste-based discrimination against women, $\tau_{n}^{w}$, due to increased competition. Alternatively, competitiveness brought by the increase in labor supply in this sector could boost women's productivity, $\mu_{n}$, reducing gender wage gap. This change in 


\begin{tabular}{lcccc}
\hline \hline & \multicolumn{2}{c}{$(1)$} & $(2)$ & \multicolumn{2}{c}{$(3)$} & $(4)$ \\
& Tradables & \multicolumn{2}{c}{ Nontradables } \\
Dependent Variable & $\Delta_{00-91}$ & $\Delta_{10-91}$ & $\Delta_{00-91}$ & $\Delta_{10-91}$ \\
\hline \multirow{2}{*}{ RTC } & & & & \\
& $0.321^{* * *}$ & $0.580^{* * *}$ & 0.0676 & 0.134 \\
& $(0.110)$ & $(0.133)$ & $(0.0800)$ & $(0.0815)$ \\
Observations & & & & \\
R-squared & 412 & 412 & 412 & 412 \\
State FE & 0.339 & 0.555 & 0.761 & 0.848 \\
\hline \hline
\end{tabular}

Source: IBGE Census. Standard errors (in parentheses) are clustered by mesoregions. *** $\mathrm{p}<0.01,{ }^{* *} \mathrm{p}<0.05,{ }^{*} \mathrm{p}<0.1$. All regressions include only employees. Tradables: agriculture and mining, low-tech and high-tech manufacturing; Nontradables: construction, trade (sales), transportation, utilities, communications and services. Controls include 1980's level of dependent variable; 1991's level of: share of high-skilled in the population; share of women employed in the population; share of married women; share of women among those with (i) less than $8 \mathrm{y}$ of schooling, (ii) between $8 \mathrm{y}$ and $10 \mathrm{y}$ of schooling, (iii) between 11 and 14 years of schooling, (iv) more than 15 years of schooling. Regressions are weighted by average population between 1991 and 2000 or 1991 and 2010 .

Table 5.4: Share of Women in Tradables and Non-tradables

$\mu_{n}$ could occur due to selection, as low-skilled women were more displaced from the labor market than high-skilled women and low and high-skilled men (Tables C.3, C.4, C.5 and C.6 in Appendix C), increasing the share of qualified women in the labor market and, thus, their relative productivity rate.

This effect on the wage gap leads to a decline in women's relative wages in tradables, $w_{f t} / w_{f n}$, inducing a new drop in the share of women working in the tradable sector (column (4) of Table 5.2, Panel A). Columns (2) and (6) exhibit that the reduction also persisted for men and, consequently, the whole economy. As in the medium run, this effect can be a consequence of a reduction in workers' preference to work in the tradable sector (drop in $\theta_{g}$ ), since the direct effect of trade liberalization is in this sector, which could lead to a worsening in the environment conditions of this sector, such as higher risk of dismissal or less flexibility, for example. It is also possible that workers reallocation due to the shock made social norms become less rigid, with men less associated to tradables ( $X_{m}$ reduce) and/or women less associated to nontradables $\left(X_{f}\right.$ increase). Although an increase in $X_{f}$ could lead to an increase in the share of women in tradables, it was not sufficient to overcome the effect of relative wages, $w_{f t} / w_{f n}$. As the losses were again greater for women in proportional terms, there was a new reduction in the share of women among workers in tradables (column (2) of Table 5.4). 


\begin{tabular}{lcccc}
\hline \hline & $(1)$ & $(2)$ & $(3)$ & $(4)$ \\
Dependent Variable & $\Delta_{00-91}$ Women & $\Delta_{00-91}$ Men & $\Delta_{10-91}$ Women & $\Delta_{10-91}$ Men \\
\hline RTC & $0.400^{* * *}$ & $0.161^{*}$ & 0.0940 & $-0.255^{* *}$ \\
& $(0.102)$ & $(0.0939)$ & $(0.148)$ & $(0.112)$ \\
Observations & & & & \\
R-squared & 412 & 412 & 412 & 412 \\
State FE & 0.678 & 0.452 & 0.754 & 0.798 \\
\hline \hline
\end{tabular}

Source: IBGE Census. Standard errors (in parentheses) are clustered by mesoregions. ${ }^{* * *}$ $\mathrm{p}<0.01,{ }^{* *} \mathrm{p}<0.05,{ }^{*} \mathrm{p}<0.1$. Occupation rate is the share of population able to work that are employed. Controls include 1980's level of dependent variable; 1991's level of: share of high-skilled in the population; share of women employed in the population; share of married women; share of women among those with (i) less than 8y of schooling, (ii) between $8 \mathrm{y}$ and $10 \mathrm{y}$ of schooling, (iii) between 11 and 14 years of schooling, (iv) more than 15 years of schooling. Regressions are weighted by average population between 1991 and 2000 or 1991 and 2010.

Table 5.5: Occupation Rate

Columns (2), (4) and (6) of Table 5.2, Panel B, show that the increase in employment in non-tradables persisted only for men in the long run, but this effect was not sufficient to induce a significant change in the share of women among workers in non-tradables (Table 5.4, column (4)). The effects on participation dissipated in the long run (Table 5.6, columns (3) and (4)), and there was no effect in the share of women among occupied workers (column (2) of Table 5.7). In columns (3) and (4) of Table 5.5, we see that there was no more losses in women's employment, while men reverted medium-term effect, increasing their occupation rate.

Table 5.8 presents a summary of all the results discussed. We observed that the effects were mainly concentrated in the medium run. The difference between genders of workers' reallocation across sectors and the greater decline in women's employment rate led to an increase in the conditional wage gap. These results evidence the crucial role of the occupation rate and the workers' distribution in influencing gender inequality. The overall job losses disappeared in the long run, but the decline in jobs in the tradable sector remained, as well as the share of women in this sector, while men's occupation rate increased. In this period, the regional tariff change led to a decrease in the conditional wage gap in non-tradables, that may have occurred due to a reduction in taste-based discrimination and/or an increase in women's productivity.

One may argue that the timing of trade liberalization used in the empirical exercise - 1990-1995 - could bias the estimations. However, the literature already show that the changes in this period are highly correlated 


\begin{tabular}{lcccc}
\hline \hline & $(1)$ & $(2)$ & $(3)$ & $(4)$ \\
Dependent Variable & $\Delta_{00-91}$ Women & $\Delta_{00-91}$ Men & $\Delta_{10-91}$ Women & $\Delta_{10-91}$ Men \\
\hline RTC & $0.170^{* *}$ & -0.0302 & 0.0615 & -0.158 \\
& $(0.0840)$ & $(0.0487)$ & $(0.123)$ & $(0.0975)$ \\
Observations & & & & \\
R-squared & 412 & 412 & 412 & 412 \\
State FE & 0.608 & 0.709 & 0.784 & 0.798 \\
\hline \hline
\end{tabular}

Source: IBGE Census. Standard errors (in parentheses) are clustered by mesoregions. ${ }^{* * *}$ $\mathrm{p}<0.01,{ }^{* *} \mathrm{p}<0.05, * \mathrm{p}<0.1$. Participation rate is the share of population able to work that are employed or searching for a job (unemployed). Controls include 1980's level of dependent variable; 1991's level of: share of high-skilled in the population; share of women employed in the population; share of married women; share of women among those with (i) less than 8y of schooling, (ii) between $8 \mathrm{y}$ and 10y of schooling, (iii) between 11 and 14 years of schooling, (iv) more than 15 years of schooling. Regressions are weighted by average population between 1991 and 2000 or 1991 and 2010.

Table 5.6: Participation Rate

with changes between 1990 and 2000 - 0.985 (2). (18) also show that the results using changes between 1990 and 1998 or 1987 and 1995 are very similar to those using 1990-1995 period. Besides that, (17) compared the results using nominal tariffs and the effective rates of protection and find similar coefficients in both cases. Finally, another concern is that these results may be influenced by migration patterns - out-migration from harder hit regions or in-migration to less adversely affected local economies. But (1) show that there is no significant effect of the local trade shock in initial region of the worker on her probability of working in a different region afterwards. They also show that the trade liberalization had no significant effect on working-age population and in-migration to harder hit regions remained, but the workers avoided the formal sector. Despite these well-established evidences, I will run robustness exercises in the future using these specifications to analyze the consistency of this paper' results.

\section{2}

\section{Potential Consequences of Labor Market Effects}

To investigate the labor market effects of trade liberalization is important per se, but also because people make decisions based on what they expect for the future. Thus, changes in the labor market can induce people to alter their choices about human capital accumulation and marital decisions. In this section, I analyze these two aspects that could be changing by virtue of labor market adjustments. Relative to education, changes could occur if individuals 


\begin{tabular}{lll}
\hline \hline & $(1)$ & $(2)$ \\
Dependent Variable & $\Delta_{00-91}$ & $\Delta_{10-91}$ \\
\hline \multirow{2}{*}{ RTC } & $\begin{array}{l}0.121^{* * *} \\
(0.0364)\end{array}$ & 0.0531 \\
& & $(0.0432)$ \\
& & \\
Observations & 412 & 412 \\
R-squared & 0.775 & 0.905 \\
State FE & Yes & Yes \\
\hline \hline
\end{tabular}

Source: IBGE Census. Standard errors (in parentheses) are clustered by mesoregions. $\mathrm{p}<0.01,{ }^{* *} \mathrm{p}<0.05,{ }^{*} \mathrm{p}<0.1$. Controls include 1980's level of dependent variable; 1991's level of: share of high-skilled in the population; share of women employed in the population; share of married women; share of women among those with (i) less than 8y of schooling, (ii) between 8y and 10y of schooling, (iii) between 11 and 14 years of schooling,

(iv) more than 15 years of schooling. Regressions are weighted by average population between 1991 and 2000 or 1991 and 2010.

Table 5.7: Share of Women Among Occupied

perceive a labor market more demanding in skills and decide to invest in human capital formation. Here, I analyze this aspect investigating possible changes in years of schooling and the share of high-school graduates. With respect to marital decisions, when facing a negative economic shock and a stressful environment, individuals possibly decide to postpone or give up their marriage and parenthood plans. Thus, I investigate the effect of trade liberalization on the share of women that have children and are married.

\subsection{1}

\section{Human Capital Accumulation}

The trade shock affected competition and displaced workers, in particular in the tradable sector, augmenting the share of non-employed people. Thus, there was an increase in the share of workers searching for a job, increasing the competition in the labor market. Therefore, it is plausible that employers become more demanding when hiring workers. This effect is consistent with results in Panel A of Table 5.9, which shows that both in the medium and long run the share of skilled workers among those who are employed increased for women and men (here I call skilled workers those who are at least high school graduates).

This response could be only a matter of screening: if there are more workers searching for the same jobs, the employer prefers to hire those who 


\begin{tabular}{lcc}
\hline \hline & Medium term & Long term \\
\hline Conditional Wage Gap in Tradables & No effect & No effect \\
Conditional Wage Gap in Nontradables & No effect & Decrease \\
Conditional Wage Gap - Total & Increase & No effect \\
\hline Women in Tradables & Decrease & Decrease \\
Women in Nontradables & Increase & No effect \\
Men in Tradables & Decrease & Decrease \\
Men in Nontradables & Increase & Increase \\
\hline Share of Women in Tradables & Decrease & Decrease \\
Share of Women in Nontradables & No effect & No effect \\
\hline Women's Occupation Rate & Decrease & No effect \\
Men's Occupation Rate & Decrease & Increase \\
Women's Participation Rate & Decrease & No effect \\
Men's Participation Rate & No effect & No effect \\
\hline Share of Women among Occupied & Decrease & No effect \\
\hline \hline
\end{tabular}

Table 5.8: Summary of Medium and Long-term Effects

are more qualified. To examine if this effect is just a reaction from employers and there is no impact in workers' decisions, I also run this exercise using the labor force (those workers who are employed or unemployed, but searching for a job) and the whole population. The results in Panels B and C of Table 5.9 point that this was not the case. There is a persistent impact of the regional tariff change on the share of skilled individuals in the population and in the workforce, indicating that individuals are becoming more educated ${ }^{1}$. Note, however, that this effect is greater for men. This could be confusing at first, as the labor market effects were relatively worse for women, but it is plausible as men's labor force was less qualified at the baseline (the share of skilled men in the workforce was 11 percent in 1991, while for women this share was 26\%). Besides that, as less-skilled women were more displaced from the workforce, men faced competition from more skilled women and had to catch up their educational level.

Finally, in Table 5.10 we see that in the medium run there was a statistically significant increase in years of schooling only for men (column (2)), but in the long run, with the persistence of competitive pressure, both women and men experienced an increase in years of schooling. In quantitative terms, moving from 90th percentile to 10th percentile of the regional tariff

${ }^{1}$ As the literature found no significant effect of the Brazilian trade liberalization on changes in the working-age population (1), it is unlikely that this effect is a consequence of different migration patterns by level of skill. 


\begin{tabular}{|c|c|c|c|c|}
\hline Dependent Variable & $\Delta_{00-91} \stackrel{(1)}{ }$ Women & $\begin{array}{c}(2) \\
\Delta_{00-91} \text { Men }\end{array}$ & $\begin{array}{c}(3) \\
\Delta_{10-91} \text { Women }\end{array}$ & $\begin{array}{c}(4) \\
\Delta_{10-91} \text { Men }\end{array}$ \\
\hline \multicolumn{5}{|c|}{ Panel A: Among Occupied } \\
\hline RTC & $\begin{array}{c}-0.279^{* * *} \\
(0.0816)\end{array}$ & $\begin{array}{c}-0.299 * * * \\
(0.0617)\end{array}$ & $\begin{array}{c}-0.300^{*} \\
(0.152)\end{array}$ & $\begin{array}{c}-0.636^{* * *} \\
(0.120)\end{array}$ \\
\hline Observations & 412 & 412 & 412 & 412 \\
\hline R-squared & 0.745 & 0.788 & 0.652 & 0.725 \\
\hline State FE & Yes & Yes & Yes & Yes \\
\hline \multicolumn{5}{|c|}{ Panel B: In the Workforce } \\
\hline RTC & $\begin{array}{c}-0.229^{* * *} \\
(0.0786)\end{array}$ & $\begin{array}{c}-0.249^{* * *} \\
(0.0604)\end{array}$ & $\begin{array}{c}-0.314^{* *} \\
(0.149)\end{array}$ & $\begin{array}{c}-0.645^{* * *} \\
(0.119)\end{array}$ \\
\hline Observations & 412 & 412 & 412 & 412 \\
\hline R-squared & 0.758 & 0.771 & 0.658 & 0.730 \\
\hline State FE & Yes & Yes & Yes & Yes \\
\hline \multicolumn{5}{|c|}{ Panel C: In the Population } \\
\hline RTC & $\begin{array}{c}-0.152^{* * *} \\
(0.0531)\end{array}$ & $\begin{array}{c}-0.237^{* * *} \\
(0.0534)\end{array}$ & $\begin{array}{c}-0.390^{* * *} \\
(0.117)\end{array}$ & $\begin{array}{c}-0.645^{* * *} \\
(0.110)\end{array}$ \\
\hline Observations & 412 & 412 & 412 & 412 \\
\hline R-squared & 0.796 & 0.782 & 0.689 & 0.748 \\
\hline State FE & Yes & Yes & Yes & Yes \\
\hline
\end{tabular}

Source: IBGE Census. Standard errors (in parentheses) are clustered by mesoregions. ${ }^{* * *}$ $\mathrm{p}<0.01,{ }^{* *} \mathrm{p}<0.05,{ }^{*} \mathrm{p}<0.1$. Skilled are those with at least high school complete. Controls include 1980's level of dependent variable; 1991's level of: share of women employed in the population; share of married women; share of women among those with (i) less than $8 \mathrm{y}$ of schooling, (ii) between $8 \mathrm{y}$ and 10y of schooling, (iii) between 11 and 14 years of schooling,

(iv) more than 15 years of schooling. Regressions are weighted by average population between 1991 and 2000 or 1991 and 2010.

Table 5.9: Share of Skilled Individuals

change means a rise in 0.16 year of schooling for women and 0.36 year for men (almost 10 percent of men's average of schooling in 1991). Again, the effect is larger for men due to a lower baseline average (3.83 for men versus 4.07 for women). These results are different from those in (28), as they find a decrease in the years of education of women and men. This is due to the absence of control for pre-existing trend in their specifications, because when I run my specification without the 1980's level of dependent variable, the point estimate is positive for women and nearly zero for men, although both become statistically insignificant.

\section{2 .2}




\begin{tabular}{lcccc}
\hline \hline & $(1)$ & $(2)$ & $(3)$ & $(4)$ \\
Dependent Variable & $\Delta_{00-91}$ Women & $\Delta_{00-91}$ Men & $\Delta_{10-91}$ Women & $\Delta_{10-91}$ Men \\
\hline & & & & \\
RTC & -0.771 & $-1.263^{* *}$ & $-1.493^{*}$ & $-3.054^{* * *}$ \\
& $(0.542)$ & $(0.494)$ & $(0.862)$ & $(0.808)$ \\
Observations & & & & \\
R-squared & 412 & 412 & 412 & 412 \\
State FE & 0.741 & 0.770 & 0.815 & 0.819 \\
\hline \hline
\end{tabular}

Source: IBGE Census. Standard errors (in parentheses) are clustered by mesoregions. *** $\mathrm{p}<0.01,{ }^{* *} \mathrm{p}<0.05,{ }^{*} \mathrm{p}<0.1$. Controls include 1980's level of dependent variable; 1991's level of: share of women employed in the population; share of married women; share of women among those with (i) less than $8 \mathrm{y}$ of schooling, (ii) between $8 \mathrm{y}$ and $10 \mathrm{y}$ of schooling, (iii) between 11 and 14 years of schooling, (iv) more than 15 years of schooling. Regressions are weighted by average population between 1991 and 2000 or 1991 and 2010.

Table 5.10: Years of Schooling

\section{Marriage Market}

The following exercise is inspired by (15), but different in the sense that they analyze the effects on marriage market of a negative shock for men in the labor market. Their exercise investigates the empirical evidences of $(33,34)$ 's theory which argues that worse outcomes for men and better outcomes for women in the labor market tend to reduce marriage rates. In this section, I analyze the consequences for the marriage market of a negative economic shock which worsened labor market conditions.

We saw in section 5.1 that trade liberalization led to a decrease in the employment level in the medium run, with persistent effects for the tradable sector in the long run. This negative economic shock implied a worsening in labor market conditions. This deterioration could imply in a more stressful environment for families, making people change their decisions about marriage and having children. Here, I study the net effect of the regional tariff change on the share of women up to 40 years old that (a) are married and (b) have at least one children. I restrict the age to 40 years because of the usual period of family formation decisions that could be affected. I present the results in Table 5.11.

In both cases, we see persistent negative effects of liberalization on marriage market. Panel A of Table 5.11 shows that regions facing greater tariff cuts experienced larger declines in the share of women that are married in the medium run (column (1)) and this effect was even greater and more significant in the long run (column (2)). In column (1) of Table 5.11, Panel B, we see a small and marginally significant effect of the RTC on the share of women 


\begin{tabular}{lcc}
\hline \hline & $(1)$ & $(2)$ \\
Dependent Variable & $\Delta_{00-91}$ & $\Delta_{10-91}$ \\
\hline \multicolumn{3}{c}{${ }^{2}$} \\
Panel A: Share of Married Women \\
RTC & $0.106^{* *}$ & $0.171^{* * *}$ \\
& $(0.0417)$ & $(0.0580)$ \\
& & \\
Observations & 412 & 412 \\
R-squared & 0.668 & 0.695 \\
State FE & Yes & Yes \\
& & \\
Panel B: Share of Women that Have Children \\
RTC & $0.0920^{*}$ & $0.213^{* * *}$ \\
& $(0.0544)$ & $(0.0634)$ \\
& & \\
Observations & 412 & 412 \\
R-squared & 0.755 & 0.781 \\
State FE & Yes & Yes \\
\hline \hline
\end{tabular}

Source: IBGE Census. Standard errors (in parentheses) are clustered by mesoregions. ${ }^{*}$ $\mathrm{p}<0.01,{ }^{*} \mathrm{p}<0.05,{ }^{*} \mathrm{p}<0.1$. The estimation include only women up to 40 years old. Controls include 1980's level of dependent variable; 1991's level of: share of high-skilled in the population; share of women employed in the population; share of women among those with (i) less than $8 \mathrm{y}$ of schooling, (ii) between $8 \mathrm{y}$ and $10 \mathrm{y}$ of schooling, (iii) between 11 and 14 years of schooling, (iv) more than 15 years of schooling. Regressions are weighted by average population between 1991 and 2000 or 1991 and 2010 .

Table 5.11: Marriage Market

that have children, but column (2) shows a larger and significant effect of the regional tariff change on the proportion of women with children in the long run. The interpretation of magnitude is as follows: a variation of -0.11 log-points in the RTC (moving from 90th percentile to 10th percentile of RTC) imply a reduction of 1.81 percentage points in the share of married women, half of the change from 1991 to 2010 (70\% to 66\%), and 2.26 percentage points in the share of women that have children, $3.2 \%$ of reduction relative to the baseline of $71 \%$. 


\section{6 \\ Conclusion}

This paper investigates the effects of Brazilian trade liberalization on gender inequality. I do this by studying the trade shock effects on labor market outcomes for women and men and providing a conceptual model to rationalize the empirical results. Besides that, I also examine potential consequences of these changes to individuals' human capital accumulation and the marriage market. Results indicate that women experienced more losses in employment and wages relative to men in the medium run. In light of the model, these effects reinforce (7)'s argument that the distribution of genders among sectors is important per se as an indicator of equality degree, as changes in distributions of these workers may have consequences to the wage gap in the economy even with no changes in productivity or discrimination, as we observed empirically. Thus, diminishing stereotypes and eliminating occupational segregation would help to promote gender equality in the labor market. In the long run, although there were still losses in the tradable sector employment, the aggregated employment losses disappeared and the wage gap in nontradables decreased. This result seems to support the need of competition as one mechanism to reduce inequality in the long run. Overall, the results point the importance of both dimensions of labor market inequality - wages and workers' distribution across occupations. I also find that there was an increase in years of education and in the share of population with completed high-school associated to trade liberalization, while the share of married women and the share of women that have children decreased in both medium and long run.

One limitation of this work is the use of a broad definition of occupation - tradables and non-tradables. Although this division clarify some questions, future research could use finer occupational classification to understand more accurately the division of work between genders. This analysis would help to understand the consequences of occupational segregation for inequality and what could be done for a better allocation of labor resources in the economy and reduction of gender inequality. 


\section{References}

[1] DIX-CARNEIRO, R.; KOVAK, B. K. Trade reform and regional dynamics: Evidence from 25 years of brazilian matched employer-employee data. Technical report, National Bureau of Economic Research, 2015.

[2] DIX-CARNEIRO, R.; SOARES, R. R.; ULYSSEA, G. Local labor market conditions and crime: Evidence from the brazilian trade liberalization. Technical report, Working Paper, Duke University, 2015.

[3] KLEVEN, H. J.; LANDAIS, C.; SøGAARD, J. E. Children and gender inequality: Evidence from denmark. 2016.

[4] BRUSSEVICH, M. Does trade liberalization narrow the gender wage gap? the role of sectoral mobility. Technical report, Mimeo, Purdue University, 2016.

[5] DUFLO, E. Women empowerment and economic development. Journal of Economic Literature, v. 50, n. 4, p. 1051-1079, 2012.

[6] ALTONJI, J. G.; BLANK, R. M. Race and gender in the labor market. Handbook of labor economics, v. 3, p. 3143-3259, 1999.

[7] BERGMANN, B. R. Occupational segregation, wages and profits when employers discriminate by race or sex. Eastern Economic Journal, v. 1, n. 2, p. 103-110, 1974.

[8] OOSTENDORP, R. H. Globalization and the gender wage gap. The World Bank Economic Review, 2009.

[9] GONZAGA, G.; MENEZES FILHO, N.; TERRA, C. Trade liberalization and the evolution of skill earnings differentials in brazil. Journal of International Economics, v. 68, n. 2, p. 345-367, 2006.

[10] GOLDBERG, P. K.; PAVCNIK, N. Distributional effects of globalization in developing countries. Journal of economic Literature, v. 45, n. 1, p. 39-82, 2007.

[11] TOPALOVA, P. Trade liberalization, poverty and inequality: Evidence from indian districts. In: Globalization and Poverty. University of Chicago Press, 2007. p. 291-336. 
[12] TOPALOVA, P. Factor immobility and regional impacts of trade liberalization: Evidence on poverty from india. American Economic Journal: Applied Economics, v. 2, n. 4, p. 1-41, 2010.

[13] TOPALOVA, P.; KHANDELWAL, A. Trade liberalization and firm productivity: The case of india. Review of economics and statistics, v. 93, n. 3, p. 995-1009, 2011.

[14] AUTOR, D. H.; DORN, D.; HANSON, G. H. The china syndrome: Local labor market effects of import competition in the united states. The American Economic Review, v. 103, n. 6, p. 2121-2168, 2013.

[15] AUTOR, D. H.; DORN, D.; HANSON, G. H. The labor market and the marriage market: How adverse employment shocks affect marriage, fertility, and children's living circumstances. 2015.

[16] KOVAK, B. K. Regional effects of trade reform: What is the correct measure of liberalization? The American Economic Review, v. 103, n. 5, p. 1960-1976, 2013.

[17] DIX-CARNEIRO, R.; KOVAK, B. K. Trade liberalization and the skill premium: A local labor markets approach. Technical report, National Bureau of Economic Research, 2015.

[18] HIRATA, G.; SOARES, R. R. Competition and the racial wage gap: Testing becker's model of employer discrimination. 2015.

[19] GOLDIN, C. The quiet revolution that transformed women's employment, education, and family. American Economic Review, v. 96, n. 2, p. 1-21, 2006.

[20] GOLDIN, C. A grand gender convergence: Its last chapter. The American Economic Review, v. 104, n. 4, p. 1091-1119, 2014.

[21] WEINBERG, B. A. Computer use and the demand for female workers. Industrial \& Labor Relations Review, v. 53, n. 2, p. 290-308, 2000.

[22] BLACK, S. E.; SPITZ-OENER, A. Explaining women's success: technological change and the skill content of women's work. The Review of Economics and Statistics, v. 92, n. 1, p. 187-194, 2010.

[23] ADDA, J.; DUSTMANN, C.; STEVENS, K. The career costs of children. 2016. 
[24] BLACK, S. E.; BRAINERD, E. Importing equality? the impact of globalization on gender discrimination. Industrial \& Labor Relations Review, v. 57, n. 4, p. 540-559, 2004.

[25] BØLER, E. A.; SMARZYNSKA JAVORCIK, B.; ULLTVEIT-MOE, K. H. Globalization: A woman $s$ best friend? exporters and the gender wage gap. 2015.

[26] JUHN, C.; UJHELYI, G.; VILLEGAS-SANCHEZ, C. Men, women, and machines: How trade impacts gender inequality. Journal of Development Economics, v. 106, p. 179-193, 2014.

[27] BERIK, G.; RODGERS, Y. V. D. M.; ZVEGLICH, J. E. International trade and gender wage discrimination: Evidence from east asia. Review of Development Economics, v. 8, n. 2, p. 237-254, 2004.

[28] GADDIS, I.; PIETERS, J. The gendered labor market impacts of trade liberalization: evidence from brazil. Journal of Human Resources, 2016.

[29] KUME, H.; PIANI, G.; SOUZA, C. F. A política brasileira de importação no período 1987-98: descrição e avaliação. A abertura comercial brasileira nos anos, v. 90, 2003.

[30] DIX-CARNEIRO, R. Trade liberalization and labor market dynamics. Econometrica, v. 82, n. 3, p. 825-885, 2014.

[31] BORJAS, G. J.; RAMEY, V. A. Foreign competition, market power, and wage inequality. The quarterly journal of economics, p. 1075-1110, 1995.

[32] BECKER, G. The economics of discrimination. University of Chicago Press, Chicago, 1957.

[33] BECKER, G. S. A theory of marriage: Part i. Journal of Political economy, v. 81, n. 4, p. 813-846, 1973.

[34] BECKER, G. S. A theory of marriage: Part ii. Journal of political Economy, v. 82, n. 2, Part 2, p. S11-S26, 1974. 
A

\section{Tariff Changes and Women Employment}

In section 2, I argued that the trade liberalization was not gender neutral, as women were concentrated in sectors with greater tariff cuts. Here, I present the relation of the share of women in the industries with the tariff changes, removing the outlier apparel sector, which could be causing the negative association. Note, however, that even without this sector, there is still a negative correlation, confirming the non-neutrality of the shock.

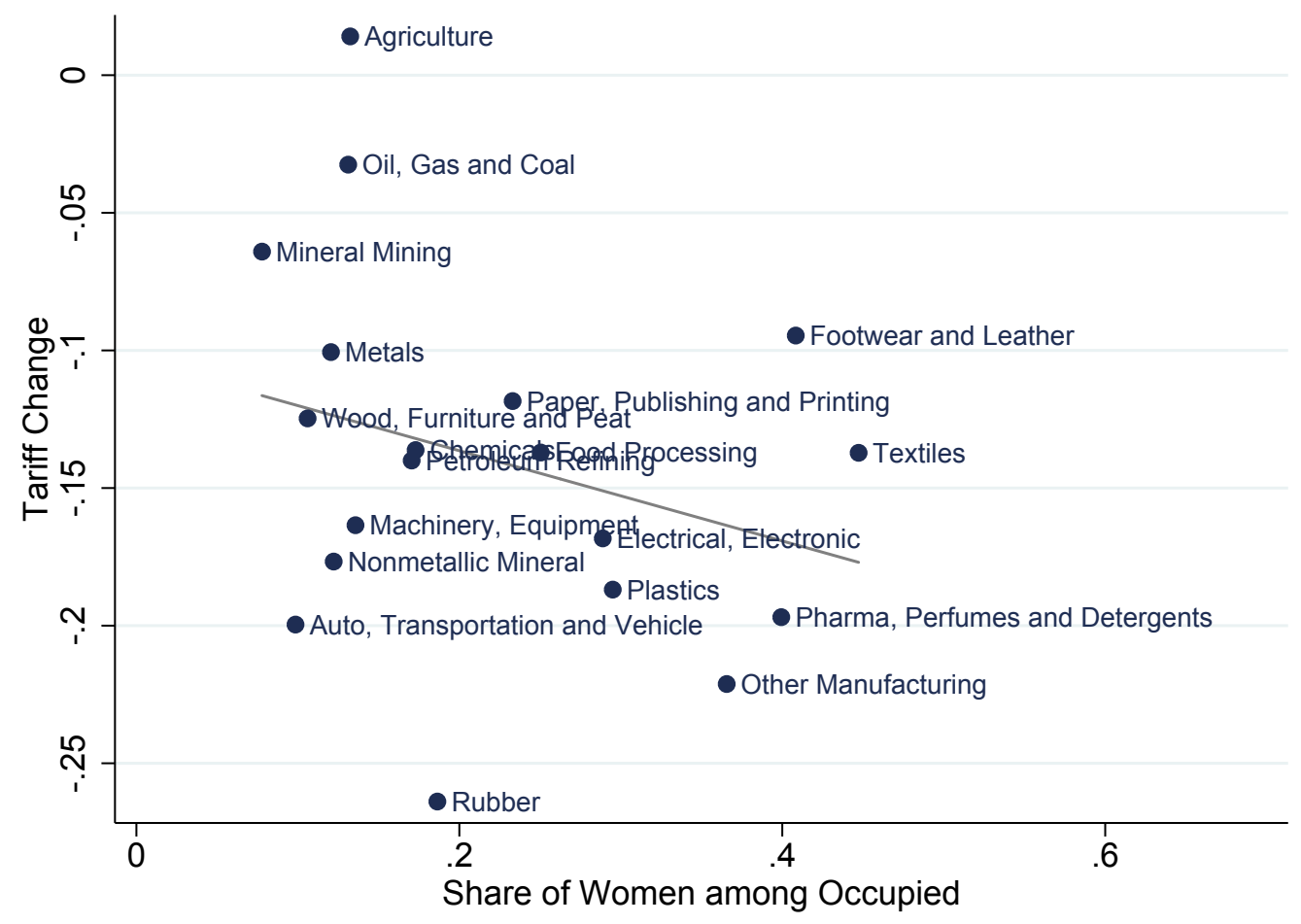

Figure A.1: Share of Women across Industries 
B

\section{Additional Statistics}

In this section I present the same summary statistics of Table 3.1 at the individual level. Note that the pattern is similar. There was an increase in years of education throughout time, with women remaining more educated than men. Women's participation rate increased, while men's participation decreased, lowering the gap between them and increasing the share of women among those employed. Finally, there was an increase in hourly wages of both genders, but the differential between them increased in the medium run (from 1.31 in 1991 to 1.36 in 2000), with a little reversal to 1.33 in 2010.

\begin{tabular}{lcccccc}
\hline \hline & \multicolumn{2}{c}{1991} & \multicolumn{2}{c}{2000} & \multicolumn{2}{c}{2010} \\
\hline & Mean & Obs. & Mean & Obs. & Mean & Obs. \\
\hline \multirow{2}{*}{$\begin{array}{l}\text { Share of Women in } \\
\text { Population }\end{array}$} & 0.51 & $8,481,287$ & 0.51 & $10,250,818$ & 0.51 & $11,294,802$ \\
& $(0.50)$ & & $(0.50)$ & & $(0.50)$ & \\
Years of Schooling & & & & & & \\
Women & 5.20 & $4,295,966$ & 6.44 & $5,157,337$ & 7.87 & $5,634,078$ \\
& $(4.33)$ & & $(4.40)$ & & $(4.60)$ & \\
Men & 5.12 & $4,185,321$ & 6.11 & $5,027,949$ & 7.31 & $5,660,724$ \\
& $(4.30)$ & & $(4.34)$ & & $(4.49)$ & \\
Participation Rate & & & & & & \\
Women & & & & & & \\
& 0.41 & $4,295,966$ & 0.55 & $5,186,546$ & 0.62 & $5,634,078$ \\
Men & $(0.49)$ & & $(0.50)$ & & $(0.49)$ & \\
& 0.91 & $4,185,321$ & 0.87 & $5,064,272$ & 0.84 & $5,660,724$ \\
Share of Women among & $(0.28)$ & & $(0.33)$ & & $(0.36)$ & \\
Occupied & 0.31 & $5,302,423$ & 0.37 & $6,347,544$ & 0.42 & $7,549,792$ \\
Average Real Hourly Wage & $(0.46)$ & & $(0.48)$ & & $(0.49)$ & \\
Women & & & & & & \\
Men & 5.15 & $1,573,155$ & 6.52 & $2,081,421$ & 8.28 & $2,803,408$ \\
& $(13.61)$ & & $(18.14)$ & & $(31.98)$ & \\
& 6.46 & $3,646,988$ & 7.88 & $3,804,539$ & 9.61 & $4,279,370$ \\
& $(15.82)$ & & $(29.26)$ & & $(74.80)$ & \\
\hline \hline
\end{tabular}

Source: Census (IBGE). Standard deviations in parenthesis. Statistics are at the individual level. Real wages are in $2010 \mathrm{R} \$$. Mean conditional wage gap is the average of first step estimations.

Table B.1: Labor Market Summary Statistics 


\section{Additional Results}

Tables C.1 and C.2 show the distribution of effects of the regional tariff change between employees and self-employed. We observe that the loss of jobs occurred for both groups and the effect was present in the medium and long run, but employees were the most negatively affected in proportional terms.

\begin{tabular}{|c|c|c|c|c|c|c|}
\hline \multirow[b]{3}{*}{ Dependent Variable } & \multirow{2}{*}{\multicolumn{2}{|c|}{ 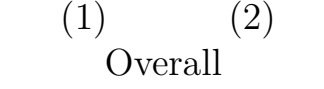 }} & (3) & (4) & (5) & (6) \\
\hline & & & \multicolumn{2}{|c|}{ Women } & \multicolumn{2}{|c|}{ Men } \\
\hline & $\Delta_{00-91}$ & $\Delta_{10-91}$ & $\Delta_{00-91}$ & $\Delta_{10-91}$ & $\Delta_{00-91}$ & $\Delta_{10-91}$ \\
\hline RTC & $\begin{array}{c}0.538^{* * *} \\
(0.128)\end{array}$ & $\begin{array}{c}0.286^{* *} \\
(0.125)\end{array}$ & $\begin{array}{c}0.361^{* * *} \\
(0.114)\end{array}$ & $\begin{array}{c}0.155 \\
(0.116)\end{array}$ & $\begin{array}{c}0.797^{* * *} \\
(0.147)\end{array}$ & $\begin{array}{c}0.411^{* * *} \\
(0.150)\end{array}$ \\
\hline Observations & 412 & 412 & 412 & 412 & 412 & 412 \\
\hline R-squared & 0.867 & 0.813 & 0.705 & 0.804 & 0.893 & 0.895 \\
\hline State FE & Yes & Yes & Yes & Yes & Yes & Yes \\
\hline
\end{tabular}

Source: IBGE Census. Standard errors (in parentheses) are clustered by mesoregions. $\mathrm{p}<0.01,{ }^{* *} \mathrm{p}<0.05,{ }^{*} \mathrm{p}<0.1$. Controls include 1980's level of dependent variable; 1991's level of: share of high-skilled in the population; share of women employed in the population; share of married women; share of women among those with (i) less than $8 \mathrm{y}$ of schooling, (ii) between 8y and 10y of schooling, (iii) between 11 and 14 years of schooling,

(iv) more than 15 years of schooling. Regressions are weighted by average population between 1991 and 2000 or 1991 and 2010.

Table C.1: Share of Employees 


\begin{tabular}{lcccccc}
\hline \hline & \multicolumn{2}{c}{$(1)(2)$} & \multicolumn{2}{c}{$(3)$} & $(4)$ & \multicolumn{2}{c}{$(5)$} & \multicolumn{2}{c}{$(6)$} \\
& \multicolumn{2}{c}{ Overall } & \multicolumn{2}{c}{ Women } & \multicolumn{2}{c}{ Men } \\
Dependent Variable & $\Delta_{00-91}$ & $\Delta_{10-91}$ & $\Delta_{00-91}$ & $\Delta_{10-91}$ & $\Delta_{00-91}$ & $\Delta_{10-91}$ \\
\hline \multirow{2}{*}{ RTC } & & & & & & \\
& $0.194^{* *}$ & $0.247^{* * *}$ & 0.0666 & $0.191^{* * *}$ & $0.333^{* *}$ & $0.313^{* *}$ \\
& $(0.0852)$ & $(0.0847)$ & $(0.0444)$ & $(0.0654)$ & $(0.145)$ & $(0.143)$ \\
Observations & 412 & 412 & 412 & 412 & 412 & 412 \\
R-squared & 0.746 & 0.848 & 0.542 & 0.691 & 0.783 & 0.884 \\
State FE & Yes & Yes & Yes & Yes & Yes & Yes \\
\hline \hline
\end{tabular}

Source: IBGE Census. Standard errors (in parentheses) are clustered by mesoregions. ${ }^{* * *}$ $\mathrm{p}<0.01,{ }^{* *} \mathrm{p}<0.05,{ }^{*} \mathrm{p}<0.1$. Controls include 1980's level of dependent variable; 1991's level of: share of high-skilled in the population; share of women employed in the population; share of married women; share of women among those with (i) less than 8y of schooling, (ii) between 8y and 10y of schooling, (iii) between 11 and 14 years of schooling, (iv) more than 15 years of schooling. Regressions are weighted by average population between 1991 and 2000 or 1991 and 2010.

Table C.2: Share of Self-Employed 


\section{C.1 Exploring Additional Heterogeneity}

In section 5 we saw that the reallocation caused by the trade shock led to an increase in non-employment in the medium run. Here, I look at the heterogeneity of this effect between low and high skilled workers. We see again that the effects on occupation and participation rates occurred mainly in the medium run (columns (1) and (2) of Tables C.3, C.4, C.5 and C.6). The losses in jobs were concentrated in low-skilled workers, though there was also a decrease in the occupation rate of high-skilled men. Once again, women were more negatively affected in proportional terms. Table C.7 shows the net effect of the changes in occupation. In the medium run, the share of women among low-skilled workers reduced, while in the long run there was a decline in the share of women among high-skilled workers.

These effects seem compatible with those observed above: as low-skilled workers were more negatively affected, there was an incentive to them to improve their level of education. Besides that, the literature already documented that trade shocks impact low-skilled workers more negatively (see (10)).

In Table C.8, I present the distribution of changes in conditional wage gap between workers' levels of skill. In the medium run (Panel A), we observe an increase in the wage gap for both levels, but the effect is significant only for high-skilled workers. However, in the long run (Panel B) this effect was reverted and there was a reduction in the conditional wage gender gap, but the coefficient is only marginally significant for high-skilled.

\begin{tabular}{lcccc}
\hline \hline & $(1)$ & $(2)$ & $(3)$ & $(4)$ \\
Dependent Variable & $\Delta_{00-91}$ Women & $\Delta_{00-91}$ Men & $\Delta_{10-91}$ Women & $\Delta_{10-91}$ Men \\
\hline RTC & & & & \\
& $0.466^{* * *}$ & $0.251^{* * *}$ & 0.203 & -0.172 \\
& $(0.0998)$ & $(0.0931)$ & $(0.153)$ & $(0.128)$ \\
Observations & & & & \\
R-squared & 412 & 412 & 412 & 412 \\
State FE & 0.645 & 0.445 & 0.657 & 0.743 \\
\hline \hline
\end{tabular}

Source: IBGE Census. Standard errors (in parentheses) are clustered by mesoregions. $\mathrm{p}<0.01,{ }^{* *} \mathrm{p}<0.05,{ }^{*} \mathrm{p}<0.1$. Occupation rate is the share of population able to work that are employed. Low-skilled are workers with less than high-school. Controls include 1980's level of dependent variable; 1991's level of: share of high-skilled in the population; share of women employed in the population; share of married women; share of women among those with (i) less than $8 \mathrm{y}$ of schooling, (ii) between $8 \mathrm{y}$ and $10 \mathrm{y}$ of schooling, (iii) between 11 and 14 years of schooling, (iv) more than 15 years of schooling. Regressions are weighted by average population between 1991 and 2000 or 1991 and 2010 .

Table C.3: Occupation Rate: Low-Skilled 


\begin{tabular}{lcccc}
\hline \hline & $(1)$ & $(2)$ & $(3)$ & $(4)$ \\
Dependent Variable & $\Delta_{00-91}$ Women & $\Delta_{00-91}$ Men & $\Delta_{10-91}$ Women & $\Delta_{10-91}$ Men \\
\hline RTC & 0.151 & $0.125^{* *}$ & 0.160 & -0.0139 \\
& $(0.114)$ & $(0.0607)$ & $(0.130)$ & $(0.0696)$ \\
& & & & \\
Observations & 412 & 412 & 412 & 412 \\
R-squared & 0.519 & 0.251 & 0.787 & 0.496 \\
State FE & Yes & Yes & Yes & Yes \\
\hline \hline
\end{tabular}

Source: IBGE Census. Standard errors (in parentheses) are clustered by mesoregions. *** $\mathrm{p}<0.01,{ }^{* *} \mathrm{p}<0.05,{ }^{*} \mathrm{p}<0.1$. Occupation rate is the share of population able to work that are employed. High-skilled are workers with at least high-school complete. Controls include 1980's level of dependent variable; 1991's level of: share of high-skilled in the population;

share of women employed in the population; share of married women; share of women among those with (i) less than 8y of schooling, (ii) between 8y and 10y of schooling, (iii) between 11 and 14 years of schooling, (iv) more than 15 years of schooling. Regressions are weighted by average population between 1991 and 2000 or 1991 and 2010 .

Table C.4: Occupation Rate: High-Skilled

\begin{tabular}{lcccc}
\hline \hline & $(1)$ & $(2)$ & $(3)$ & $(4)$ \\
Dependent Variable & $\Delta_{00-91}$ Women & $\Delta_{00-91}$ Men & $\Delta_{10-91}$ Women & $\Delta_{10-91}$ Men \\
\hline & & & & \\
RTC & $0.251^{* *}$ & 0.0140 & 0.176 & -0.0691 \\
& $(0.0975)$ & $(0.0540)$ & $(0.131)$ & $(0.111)$ \\
& & & & \\
Observations & 412 & 412 & 412 & 412 \\
R-squared & 0.519 & 0.657 & 0.687 & 0.739 \\
State FE & Yes & Yes & Yes & Yes \\
\hline \hline
\end{tabular}

Source: IBGE Census. Standard errors (in parentheses) are clustered by mesoregions. ${ }^{* * *}$ $\mathrm{p}<0.01,{ }^{* *} \mathrm{p}<0.05,{ }^{*} \mathrm{p}<0.1$. Participation rate is the share of population able to work that are employed or searching for a job (unemployed). Low-skilled are workers with less than high-school. Controls include 1980's level of dependent variable; 1991's level of: share of high-skilled in the population; share of women employed in the population; share of married women; share of women among those with (i) less than 8y of schooling, (ii) between $8 \mathrm{y}$ and 10y of schooling, (iii) between 11 and 14 years of schooling, (iv) more than 15 years of schooling. Regressions are weighted by average population between 1991 and 2000 or 1991 and 2010.

Table C.5: Participation Rate: Low-Skilled 


\begin{tabular}{lcccc}
\hline \hline & $(1)$ & $(2)$ & $(3)$ & $(4)$ \\
Dependent Variable & $\Delta_{00-91}$ Women & $\Delta_{00-91}$ Men & $\Delta_{10-91}$ Women & $\Delta_{10-91}$ Men \\
\hline & & & & \\
RTC & -0.0109 & 0.0172 & 0.129 & -0.0261 \\
& $(0.119)$ & $(0.0401)$ & $(0.112)$ & $(0.0575)$ \\
& & & & \\
Observations & 412 & 412 & 412 & 412 \\
R-squared & 0.655 & 0.431 & 0.798 & 0.559 \\
State FE & Yes & Yes & Yes & Yes \\
\hline \hline
\end{tabular}

Source: IBGE Census. Standard errors (in parentheses) are clustered by mesoregions. ${ }^{* * *}$ $\mathrm{p}<0.01,{ }^{* *} \mathrm{p}<0.05,{ }^{*} \mathrm{p}<0.1$. Participation rate is the share of population able to work that are employed or searching for a job (unemployed). High-skilled are workers with at least high-school complete. Controls include 1980's level of dependent variable; 1991's level of: share of high-skilled in the population; share of women employed in the population; share of married women; share of women among those with (i) less than 8y of schooling, (ii) between $8 \mathrm{y}$ and $10 \mathrm{y}$ of schooling, (iii) between 11 and 14 years of schooling, (iv) more than 15 years of schooling. Regressions are weighted by average population between 1991 and 2000 or 1991 and 2010.

\begin{tabular}{lllll}
\hline \hline & \multicolumn{2}{c}{$(1)$} & \multicolumn{1}{c}{$(2)$} & \multicolumn{2}{c}{$(3)$} & \multicolumn{2}{c}{$(4)$} \\
Low-skilled & \multicolumn{2}{c}{ High-skilled } \\
Dependent Variable & $\Delta_{00-91}$ & $\Delta_{10-91}$ & $\Delta_{00-91}$ & $\Delta_{10-91}$ \\
\hline \multirow{2}{*}{ RTC } & $0.133^{* * * *}$ & 0.0128 & 0.00246 & $0.139^{* *}$ \\
& $(0.0467)$ & $(0.0596)$ & $(0.0571)$ & $(0.0558)$ \\
& & & & \\
Observations & 412 & 412 & 412 & 412 \\
R-squared & 0.683 & 0.801 & 0.808 & 0.885 \\
State FE & Yes & Yes & Yes & Yes \\
\hline \hline
\end{tabular}

Source: IBGE Census. Standard errors (in parentheses) are clustered by mesoregions. $\mathrm{p}<0.01,{ }^{* *} \mathrm{p}<0.05,{ }^{*} \mathrm{p}<0.1$. Low-skilled are workers with less than high-school.

High-skilled are those with at least high-school complete. Controls include 1980's level of dependent variable; 1991's level of: share of high-skilled in the population; share of women employed in the population; share of married women; share of women among those with (i)

less than $8 \mathrm{y}$ of schooling, (ii) between $8 \mathrm{y}$ and $10 \mathrm{y}$ of schooling, (iii) between 11 and 14 years of schooling, (iv) more than 15 years of schooling. Regressions are weighted by average population between 1991 and 2000 or 1991 and 2010.

Table C.7: Share of Women among Occupied by Skill 


\begin{tabular}{cccc}
\hline \hline & Overall & Low-Skilled & High-Skilled \\
& $(1)$ & $(2)$ & $(3)$ \\
Dependent Variable & $\Delta \gamma_{m}$ & $\Delta \gamma_{m}$ & $\Delta \gamma_{m}$ \\
\hline
\end{tabular}

Panel A: Medium-term (1991-2000)

$\begin{array}{lccc}\text { RTC } & -0.349^{*} & -0.327 & -0.509^{* *} \\ & (0.187) & (0.223) & (0.210) \\ \text { Observations } & 412 & 412 & 412 \\ \text { R-squared } & 0.664 & 0.598 & 0.517 \\ \text { State FE } & \text { Yes } & \text { Yes } & \text { Yes }\end{array}$

Panel B: Long-term (1991-2010)
RTC
0.151
0.209
$0.392^{*}$
(0.207)
(0.247)
(0.206)

Observations

412

412

412

R-squared

0.732

0.642

0.641

State FE

Yes

Yes

Yes

Source: IBGE Census. Standard errors (in parentheses) are clustered by mesoregions. $\mathrm{p}<0.01,{ }^{* *} \mathrm{p}<0.05,{ }^{*} \mathrm{p}<0.1$. Low-skilled are workers with less than high-school.

High-skilled are those with at least high-school complete. All regressions include 1980's level of dependent variable as control and are weighted by the inverse of first step standard errors.

Table C.8: Conditional Wage Gap by Skill 


\section{C.2}

\section{Looking at all workers}

Finally, in this section I present the results of reallocation between tradables and non-tradables including all workers instead of only employees. Panels A and B of Table C.9 show that there was a decrease in the share of workers in the tradable sector and a rise in the participation in nontradables. This reallocation led to a reduction in the share of women in tradable occupations (Table C.10). Overall, the effects are similar to those including only employees, but the magnitude and persistence are lower when I include all workers. Thus, we note that although all workers were affected by the trade liberalization, employees suffered a greater impact.

\begin{tabular}{lcccccc}
\hline \hline & \multicolumn{2}{c}{$(1)$} & \multicolumn{2}{c}{$(3)$} & $(4)$ & \multicolumn{2}{c}{$(5)$} & $(6)$ \\
& Overall & \multicolumn{2}{c}{ Women } & \multicolumn{2}{c}{ Men } \\
Dependent Variable & $\Delta_{00-91}$ & $\Delta_{10-91}$ & $\Delta_{00-91}$ & $\Delta_{10-91}$ & $\Delta_{00-91}$ & $\Delta_{10-91}$ \\
\hline \multirow{3}{*}{ Panel A: Tradables } & & & & & & \\
RTC & & & & & & \\
& $0.341^{* * *}$ & 0.206 & $0.333^{* * *}$ & $0.263^{*}$ & $0.337^{* * *}$ & 0.147 \\
Observations & $(0.103)$ & $(0.152)$ & $(0.103)$ & $(0.141)$ & $(0.119)$ & $(0.178)$ \\
R-squared & 412 & 412 & 412 & 412 & 412 & 412 \\
State FE & 0.426 & 0.577 & 0.640 & 0.646 & 0.727 & 0.836 \\
& Yes & Yes & Yes & Yes & Yes & Yes \\
Panel B: Nontradables & & & & & & \\
RTC & $-0.144^{* *}$ & -0.111 & -0.0470 & -0.0967 & $-0.249^{* * *}$ & -0.156 \\
& $(0.0596)$ & $(0.0934)$ & $(0.0709)$ & $(0.0946)$ & $(0.0715)$ & $(0.115)$ \\
Observations & 412 & 412 & 412 & 412 & 412 & 412 \\
R-squared & 0.761 & 0.755 & 0.705 & 0.774 & 0.813 & 0.824 \\
State FE & Yes & Yes & Yes & Yes & Yes & Yes \\
\hline \hline
\end{tabular}

Source: IBGE Census. Standard errors (in parentheses) are clustered by mesoregions. *** $\mathrm{p}<0.01,{ }^{* *} \mathrm{p}<0.05,{ }^{*} \mathrm{p}<0.1$. This is the share of all workers in tradables and nontradables over the working age population. Tradables: agriculture and mining, low-tech and high-tech manufacturing; Nontradables: construction, trade (sales), transportation, utilities, communications and services. Controls include 1980's level of dependent variable;

1991's level of: share of high-skilled in the population; share of women employed in the population; share of married women; share of women among those with (i) less than $8 \mathrm{y}$ of schooling, (ii) between 8y and 10y of schooling, (iii) between 11 and 14 years of schooling,

(iv) more than 15 years of schooling. Regressions are weighted by average population between 1991 and 2000 or 1991 and 2010.

Table C.9: Share of Tradables and Non-tradables 


\begin{tabular}{lcccc}
\hline \hline & \multicolumn{2}{c}{$(1)$} & $(2)$ & \multicolumn{2}{c}{$(3)$} & $(4)$ \\
& \multicolumn{2}{c}{ Tradables } & \multicolumn{2}{c}{ Nontradables } \\
Dependent Variable & $\Delta_{00-91}$ & $\Delta_{10-91}$ & $\Delta_{00-91}$ & $\Delta_{10-91}$ \\
\hline \multirow{2}{*}{ RTC } & & & & \\
& $0.287^{* * *}$ & $0.328^{* *}$ & 0.0498 & -0.0657 \\
& $(0.109)$ & $(0.139)$ & $(0.0572)$ & $(0.0589)$ \\
Observations & & & & \\
R-squared & 412 & 412 & 412 & 412 \\
State FE & 0.539 & 0.666 & 0.731 & 0.838 \\
\hline \hline
\end{tabular}

Source: IBGE Census. Standard errors (in parentheses) are clustered by mesoregions. *** $\mathrm{p}<0.01,{ }^{* *} \mathrm{p}<0.05,{ }^{*} \mathrm{p}<0.1$. Regressions include all individuals employed. Tradables: agriculture and mining, low-tech and high-tech manufacturing; Nontradables: construction, trade (sales), transportation, utilities, communications and services. Controls include 1980's level of dependent variable; 1991's level of: share of high-skilled in the population; share of women employed in the population; share of married women; share of women among those with (i) less than 8y of schooling, (ii) between 8y and 10y of schooling, (iii) between 11 and 14 years of schooling, (iv) more than 15 years of schooling. Regressions are weighted by average population between 1991 and 2000 or 1991 and 2010 .

Table C.10: Share of Women in Tradables and Non-tradables 